Tanrıkulu, F. (2017). EBA’nın Türkçe dersi öğrenme alanlarını karşılama yeterliliğine yönelik öğretmen görüşleri. Ana Dili Eğitimi Dergisi, 5(3), 395-416.

$\begin{gathered}\text { Ana Dili Eğitimi Dergisi } \\ \text { Journal of Mother Tongue Education } \\ \text { www.anadiliegitimi.com }\end{gathered}$
Geliş/Received: 06.04 .2017 Kabul/Accepted:07.06.2017

\title{
EBA’nın Türkçe Dersi Öğrenme Alanlarını Karşılama Yeterliliğine Yönelik Öğretmen Görüşleri
}

\author{
Fatih TANRIKULU*
}

Öz

Bu araştırma, Türkçe dersi öğrenme alanlarına ait EBA içeriklerinin yeterliliğine yönelik öğretmen görüşlerini tespit etmeyi amaçlamaktadır. Araştırma durum çalışması modelinde yapılmıştır. Araştırmanın çalışma grubunu 24 Türkçe öğretmeni oluşturmaktadır. Araştırmada veri toplama aracı olarak araştırmacı tarafından geliştirilen yarı yapılandırılmış görüşme formu kullanılmıştır. Açık uçlu sorulardan oluşan görüşme formundaki sorulara Türkçe Eğitimi Anabilim Dalında çalışan öğretim üyelerinden iki uzman görüşü alınarak son hali verilmiştir. Görüşme formuyla elde edilen veriler Nvivo 11 nitel veri analizi programına yüklenerek içerik analizi yapılmıştır. Oluşturulan kodlar araştırma soruları altında temalaştırılmıştır. Bulguların daha anlaşılır ve sade olması için Nvivo 11 programının grafik özelliklerinden faydalanılmıştır. Araştırma sonucunda EBA içeriklerinin öğrenme alanlarını karşılamada yetersiz olduğu belirlenmiştir. Konuşma, dinleme, okuma, yazma ve dil bilgisi alanlarının her birine yönelik hazırlanan içeriklerin istenilen düzeyde olmadığı, dinleme ve yazma alanlarına yönelik içeriklerin diğerlerine oranla daha yetersiz olduğu bulgularda görülmüştür.

Anahtar Kelimeler: Türkçe öğretimi, Teknoloji kullanımı, Öğrenme alanları, EBA (Eğitim Bilişim Ağı)

\section{Teacher Opinions on EBA Content's Satisfying Turkish Language Course Learning Areas Outcomes}

\begin{abstract}
This research aims to determine the opinions of teachers on the adequacy of the EBA content for satisfying Turkish language learning areas outcomes. The research was conducted as a case study. The research group of the study was composed of 24 Turkish teachers. A semi-structured interview form developed by the researcher was used as the data collection tool in the research. The questions in the interview form, consisting of open ended questions, were given their final form by obtaining the opinions of two experts who were working as faculty members in the Turkish Education Department. The data obtained through the interview form were entered into the Nvivo 11 qualitative data analysis program, and content analysis was performed. The generated codes were thematized according to the research questions. In order to make the findings clearer and simpler, the graphical features of the Nvivo 11 program were used. As a result of the research, it was determined that the EBA content was inadequate in terms of satisfying the learning areas outcomes. It was found that the content prepared for each of the fields of speaking, listening, reading, writing and grammar were not at the desired level and that the contents for the listening and writing fields were inferior compared with the other fields.
\end{abstract}

Keywords: Turkish teaching, Technology usage, Learning areas, EBA (Educational Information Network)

\footnotetext{
* Yrd. Doç. Dr., Kahramanmaraş Sütçü İmam Üniversitesi, Eğitim Fakültesi, Türkçe ve Sosyal Bilimler Eğitimi Bölümü, fatih3878@hotmail.com
} 


\section{Giriş}

Teknoloji günlük hayatın her alanında yaygınlaşmış, bireyi kuşatmıştır (Yalçın,2012: 14; Nuhoğlu, Hüseyin ve Ertuğrul, 2007: 99; Chen, Looi ve Chen, 2009; Herzig, 2013). Ülkemizde bilgisayar kullanım oranı \%54,9'a, internet kullanımı \%61,2'a, internet erişimi ise \%76,3'e çıkmıştır (TÜiK, 2016). Teknoloji hayatın vazgeçilmez bir parçası haline gelmiştir. Hayatla iç içe olmayı ilke edinen eğitim sisteminin teknolojiyle bütünleşmesi kaçınılmaz olmuştur (Altın ve Kalelioğlu, 2015). 1990'I yıllardan bu yana eğitimde hızla yaygınlaşan teknolojinin (Choy, Wong ve Gao, 2009) kullanımı son zamanlarda daha da hız kazanmış (Yelbay, 2015: 365) öğretim ortamı üzerindeki etkisi daha da belirgin hale gelmiştir (Chang, Sung ve Hou, 2006; Korkmaz ve Ünsal, 2016).

Teknolojinin günlük hayatta aktif kullanımını fırsata dönüştürmek için (Abe ve Jardon, 2013) dünyanın birçok ülkesi teknolojinin eğitime entegrasyonu için politikalar geliştirmekte (Bello, 2014) eğitim bakanlıkları veya kurumları çalışmalar yapmaktadır (Chen, Looi ve Chen, 2009). Bu çalışmaların başında sınıflarda interaktif beyaz tahta kullanımı gelmektedir. Eğitimde ileri seviyede olan ABD ve İngiltere'deki birçok k-12 ve yüksek okul interaktif beyaz tahta teknolojisine önemli bir yatırımlar yapmıştır (Digregorio ve Lojeski, 2010). İngiltere hükümeti öğretim ve öğrenmeyi etkilemek amacıyla IWB' lere yaklaşık 50 milyon pound yatırım yapmıştır (Clarke, 2004; Akt. Kearney ve Schuck, 2017). İngiltere ve Amerika'da birçok sınıfta IBW kullanılmaya başlanmıştır (Diegregorio ve Lojeski 2009). Ingiliz eğitim sistemini takip eden Avustralya okullarında da interaktif beyaz tahtalar aktif olarak kullanılmaktadır (Kearney ve Schuck, 2017).

Gelişmiş dünya ülkeleri sosyal ve teknolojik değişimlere paralel olarak eğitim sistemlerini sürekli yenileyerek gelişmelere uyum sağlamak için reformlar yapmaktadırlar (Öz, 2011: 22). Her alanda dünyadaki bilimsel ve teknolojik gelişmeleri takip eden ülkemiz (Yıldız, Okur, Arı ve Yılmaz, 2013) bilgi ve teknoloji ile okullarımızı donatılıp güçlendirmektedir (Kavcar, Oğuzkan ve Hasırcı, 2016: 21). Eğitimin başarıya ulaşmasında teknolojinin önemli bir yeri olduğunu (Şahin, 2007: 310; Karatay, 2014) bilen MEB, FATiH projesini başlatarak eğitimde teknolojinin aktif kullanımını sağlamıştır.

Amaç, teknolojiyi kullanmak değil, bilişim teknolojilerini bir amaca ulaşmak için etkin ve verimli kullanmaktır (Öz, 2011: 35). Okulları teknolojiyle buluşturan MEB, teknolojinin etkin kullanımında ortaya çıkabilecek her türlü durumu göz önünde bulundurulmaya çalışmıştır. Bu amaçla video, kitap, görseller, doküman, animasyon, simülasyon, etkileşimli içerikler, bireysel öğrenme materyalleri, sınıf içi öğretim materyalleri, uygulamalar, oyunlar vb. bölümlerinden oluşan bir platform hazırlamıştır (MEB, 2017). Eğitim Bilişim Ağı (EBA) adı verilen çevrim içi bir sosyal eğitim platformu olan EBA'nın amacı; okulda, evde, kısacası ihtiyaç duyulan her yerde bilgi teknolojileri araçlarını kullanarak etkili materyal kullanımını destekleyip teknolojinin eğitime entegrasyonunu 
sağlamaktır (EBA, 2017). Öğretmen ve öğrenciler başta olmak üzere eğitimin tüm paydaşları için tasarlanan EBA'nın hedefleri şöyledir:

- Farklı, zengin ve eğitici içerikler sunmak,

- Bilişim kültürünü yaygınlaştırarak eğitimde kullanılmasını sağlamak,

- İçerikle ilgili ihtiyaçlara cevap vermek,

- Sosyal ağ yapısıyla kullanıcıların bilgi alışverişinde bulunabilmelerini sağlamak,

- Zengin ve gittikçe büyüyen arşiviyle derslere katkı sağlamak,

- Bilgiyi öğrenirken aynı zamanda yeniden yapılandırabilmek ve bilgiden bilgi üretmek,

- Farklı öğrenme stillerine (sözel, görsel, sayısal, sosyal, bireysel, işitsel öğrenme) sahip öğrencileri de kapsamak,

- Bütün öğretmenleri ortak bir paydada buluşturarak eğitime el birliğiyle yön vermelerini sağlamak (EBA, 2017).

Türkçe öğretimi geleneksel sınıflar yerine, teknolojik imkânlarla desteklenerek yapılması gerekir (Sever, 2003: 37). Eğitim teknolojisinin sunduğu bu imkânlar Türkçe öğretimini daha etkili hale getirmek için kullanılmaktadır (Kavcar, Oğuzkan ve Hasırcı, 2016: 21). Teknoloji dil öğretiminde öğrenme ortamını zenginleştirerek çeşitli etkinliklerin düzenlenmesini kolaylaştırmakta (Solmaz, 2015: 424) okuma, yazma, dinleme ve konuşma becerilerinin geliştirilmesine imkân sağlamaktadır (Yılmaz, 2015: 394-395; Günşen, 2006: 190). Türkçe dersinin öğrenme alanlarından olan okuma becerisinin (Güneş, 2014: 19; Parlakyıldız, 2014), yazma becerisinin (Karadağ ve Maden, 2014: 288; Güneş, 2014: 19; Parlakyıldız, 2014; Yağmur, 2011), konuşma becerisinin (Umağan, 2007), dinleme becerisinin (Güneş, 2014: 94; Yağmur, 2011) geliştirilmesinde teknoloji aktif bir şekilde kullanılmaktadır. Teknolojiyi eğitimle birleştiren EBA'da bu becerilerin gelişmesine yönelik birçok içerik bulunmaktadır.

Tablo 1. Öğrenme alanlarına göre sınıflandırılmış Türkçe dersi EBA içerikleri

\begin{tabular}{|c|c|c|c|c|c|}
\hline & Konuşma & Dinleme & Okuma & Yazma & Dilbilgisi \\
\hline 5. Sınıf & 2 & 6 & 54 & 17 & 15 \\
\hline 6. Sınıf & 8 & 34 & 188 & 42 & 85 \\
\hline 7. Sınıf & 12 & 29 & 238 & 44 & 57 \\
\hline 8. Sınıf & 12 & 20 & 257 & 57 & 73 \\
\hline Toplam & $\mathbf{3 4}$ & $\mathbf{8 9}$ & $\mathbf{7 3 7}$ & $\mathbf{1 6 0}$ & $\mathbf{2 3 0}$ \\
\hline
\end{tabular}

EBA'da Türkçe dersinin öğrenme alanlarına yönelik çok fazla sayıda içerik bulunduğu görülmektedir. İçeriklerin temel dil becerilerinin hepsini karşılayabilecek sayıda olması dikkat çekicidir. Bu içerikler sayı olarak yeterlidir, denilebilir ama nitelik olarak nasıl olduğu bilinmemektedir. İçerikler yayınlanırken uzman incelemesinden geçmektedir. Ancak içeriği sınıfta etkin şekilde kullananlar öğretmenlerdir. Türkçe öğrenme alanlarına yönelik içeriklerinin yeterli olup olmadığını 
Türkçe öğretmenleri daha sağlıklı değerlendirebilecektir. İçeriklerin yeterli olup olmadığını ortaya koymak amacıyla aşağıdaki sorulara cevap aranmıştır:

1. Türkçe dersi öğrenme alanlarına yönelik EBA içeriklerinin yeterliliği hakkında Türkçe öğretmenlerinin düşünceleri nelerdir?

a. Konuşma becerilerini geliştirmeye yönelik EBA içeriklerinin yeterliliği hakkında Türkçe öğretmenlerinin düşünceleri nelerdir?

b. Dinleme becerilerini geliştirmeye yönelik EBA içeriklerinin yeterliliği hakkında Türkçe öğretmenlerinin düşünceleri nelerdir?

c. Okuma becerilerini geliştirmeye yönelik EBA içeriklerinin yeterliliği hakkında Türkçe öğretmenlerinin düşünceleri nelerdir?

d. Yazma becerilerini geliştirmeye yönelik EBA içeriklerinin yeterliliği hakkında Türkçe öğretmenlerinin düşünceleri nelerdir?

e. Dil bilgisi becerilerini geliştirmeye yönelik EBA içeriklerinin yeterliliği hakkında Türkçe öğretmenlerinin düşünceleri nelerdir?

\section{Yöntem}

$\mathrm{Bu}$ araştırmada nitel araştırma desenlerinden olan durum çalışması modeli kullanılmıştır. Durum çalışmasında amaç bir olguyu derinlemesine araştırmaktır. Nitel durum çalışmasının en temel özelliği bir ya da birkaç durumun derinliğine araştırılmasıdır (Yıldırım ve Şimşek, 2011). Bu araştırmada EBA Türkçe öğrenme alanlarına yönelik ders içerikleri yeterliliğini belirlemek amacıyla Türkçe öğretmenlerinin görüşlerine başvurularak EBA içerikleri hakkında kapsamlı bilgi toplamak amaçlanmıştır.

\section{Çalışma Grubu}

Çalışma grubu farkı illerde çalışan 24 Türkçe öğretmeninden oluşmaktadır. Çalışma grubunu belirlemede amaçlı örnekleme yöntemlerinden kolay ulaşılabilirlik örneklemesi tercih edilmiştir (Yıldırım ve Şimşek, 2011).

Tablo 2. Katılımcıların özellikleri

\begin{tabular}{lc}
\hline Katılımcıların Özellikleri & Katılımcı Sayısı \\
\hline Mesleki Deneyim & $\mathbf{2 4}$ \\
\hline $15 \quad$ Yıl Üzeri & 12 \\
$10-15$ Yıl & 10 \\
$0-10 \quad$ Yıl & 2 \\
\hline Şehir & $\mathbf{2 4}$ \\
\hline Kayseri & 17 \\
Kahramanmaraş & 5 \\
Ankara & 2 \\
\hline Kullanım Sıklığı (haftalık) & $\mathbf{2 4}$ \\
\hline Saat & 10 \\
1 Saat & 9 \\
\hline Saat & 5 \\
\hline
\end{tabular}


EBA’nın Türkçe Öğretim Programı Öğrenme Alanlarını Karşılama Yeterliliğine Yönelik Öğretmen Görüşleri

\section{Veri Toplama Aracı}

$\mathrm{Bu}$ araştırmada veri toplama aracı olarak açık uçlu sorulardan oluşan standartlaştırılmış görüşme formu kullanılmıştır. Yüz yüze görüşme imkânı olan öğretmenlerle birebir görüşme yapılmış, görüşme imkânı olmayan öğretmenlerle e-posta, whatsapp, massenger ile iletişime geçilerek veriler toplanmıştır.

\section{Verilerin Analizi ve Kodlanması}

Verilerin analizinde Nvivo 11 programı kullanılmıştır. Toplanan veriler word ortamına aktarılmış, Nvivo 11 programına yüklenerek kodlama yapılmıştır. Oluşturulan kodlar görüşme soruları altında temalaştırılmıştır. Görüşlerin daha iyi yansıtılması için öğretmen görüşlerindeki ifadelere yakın kod isimleri kullanılmıştır.

\section{Bulgular ve Yorum}

$\mathrm{Bu}$ bölümde çalışmada elde edilen bulgular sunulmuştur. Bulguların kolay anlaşılıp yorumlanması için Nvivo 11 programının hem grafik hem tablo özelliklerinden faydalanılmıştır. Öncelikle kodların grafiği daha sonra kodların tablosu sayı, kaynak ve kod örnekleriyle sunulmuştur.

Konuşma becerilerini geliştirmeye yönelik içeriklerin yeterliliği hakkında öğretmen görüşleri

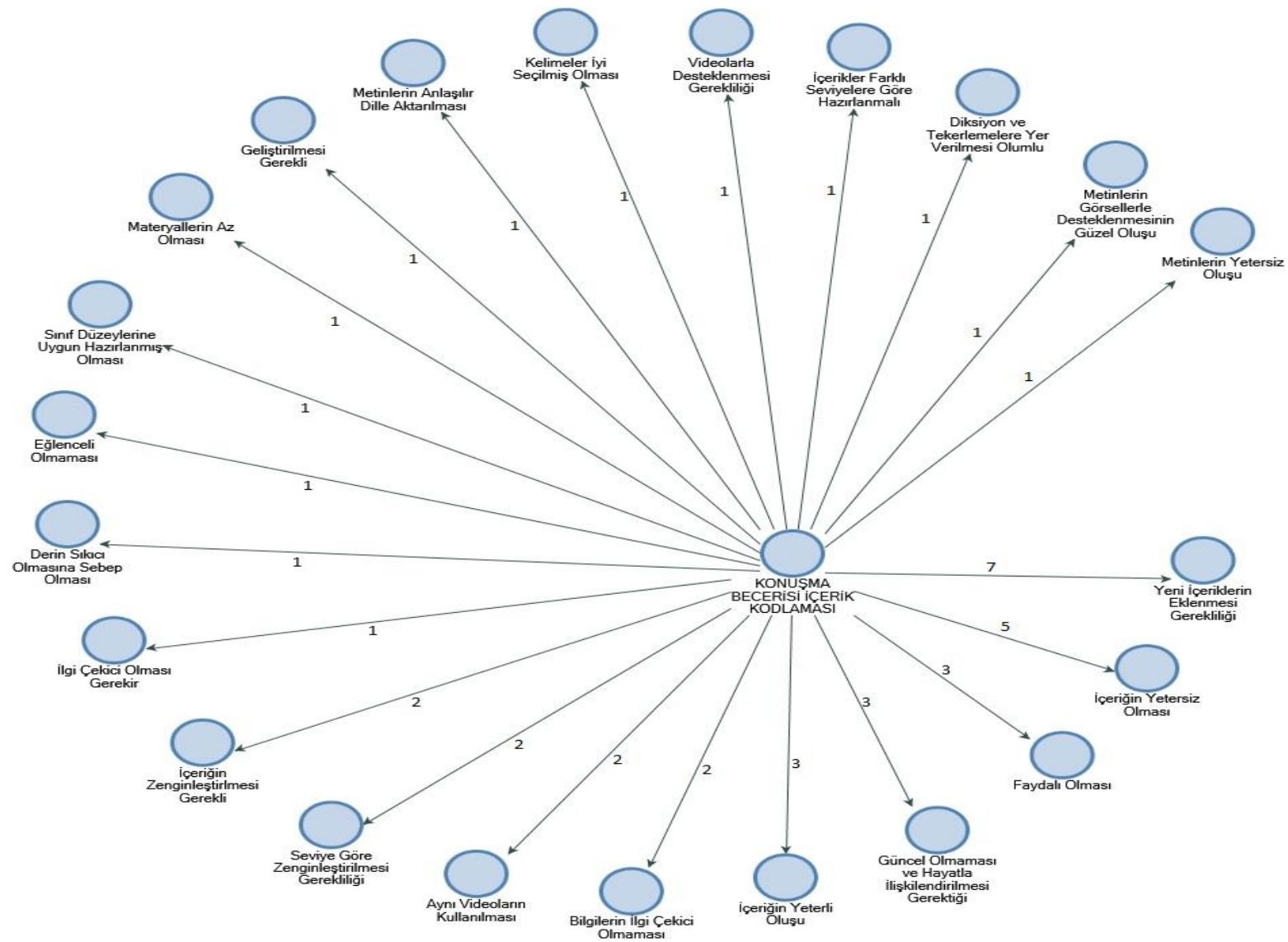

Şekil 1. Konuşma içerikleri kod grafiği 
Tablo 3. Konuşma becerisi içeriklerine ait kod tablosu

\begin{tabular}{|c|c|c|c|}
\hline Kod Adı & 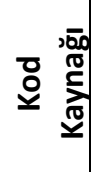 & 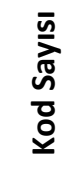 & Örnek Kodlamalar \\
\hline & 21 & 43 & \\
\hline Yeni İçeriklerin Eklenmesi Gerekliliği & 7 & 7 & $\begin{array}{l}\text { Konuşma becerisi ile ilgili video, görsel, çalışma } \\
\text { kâğıdı biraz daha artırılmalıdır. } \\
\text { Hazırlıklı konuşma metni sunumu ve diyaloglar } \\
\text { eklenebilir. }\end{array}$ \\
\hline İçeriğin Yetersiz Olması & 5 & 5 & $\begin{array}{c}\text { *EBA'da konuşma becerilerini geliştirmeye } \\
\text { yönelik içerikler yeterli değildir. } \\
\text { Konuşma becerisini geliştirecek nitelikte birkaç } \\
\text { çalışma var, o da içeriğin yetersiz olduğunu } \\
\text { gösteriyor }\end{array}$ \\
\hline Faydalı Olması & 3 & 3 & $\begin{array}{c}\text { Konuşma becerilerine yönelik. Bu içeriklerin çok } \\
\text { faydalı olduğunu düşünüyorum örnekler biraz } \\
\text { arttırılabilir. }\end{array}$ \\
\hline $\begin{array}{l}\text { Güncel Olmaması ve Hayatla } \\
\text { iliş̧ilendirilmesi Gerektiği }\end{array}$ & 3 & 3 & $\begin{array}{c}\text { Türkçenin günlük hayatta özellikle de okullarda } \\
\text { daha güzel konuşulması adına bu tür etkinliklere } \\
\text { daha fazla yer verilmesi gerektiğini } \\
\text { düşünüyorum. } \\
\text { Güncel hayatla daha çok ilişkilendirilmeli ve } \\
\text { videolarla desteklenmelidir. }\end{array}$ \\
\hline İçeriğin Yeterli Oluşu & 3 & 3 & $\begin{array}{c}\text { Bu içeriğin istenen hedefe ulaşma adına yeterli } \\
\text { olduğu düşünüyorum. }\end{array}$ \\
\hline Bilgilerin İlgi Çekici Olmaması & 2 & 2 & $\begin{array}{c}\text { Örnekler daha çok olmalı içerik geliştirilmeli } \\
\text { daha ilgi çekici ve güncel olmalı, daha eğlenceli } \\
\text { olmalı. }\end{array}$ \\
\hline
\end{tabular}

Ayrıca 6,7, ve 8. sınıf düzeyi içeriklere

Aynı Videoların Kullanılması

Seviye Göre Zenginleştirilmesi Gerekliliği

İçeriğin Zenginleştirilmesi Gerekli

İlgi Çekici Olması Gerekir

11 baktığımızda yine aynı videoların kullanıldığını görüyoruz. Burada da farklı sınıf düzeylerinde farklı içerikler hazırlanabilirdi.

Mevcut etkinlikleri faydalı buluyorum ancak metinlerin ve görsellerin yetersiz olduğunu konu ve seviyeye göre zenginleştirilmesi gerektiğini düşünüyorum.

Mevcut etkinlikleri faydalı buluyorum, ancak metinlerin ve görsellerin yetersiz olduğunu konu ve seviyeye göre zenginleştirilmesi gerektiğini düşünüyorum.

Türkçenin kurallarına göre konuşma becerilerini geliştirebileceğini düşünüyorum. Ancak örnek metinler daha ilgi çekici olmalıdır.

Konuşma becerilerini geliştirmeye yönelik düz bilgileri verilmesi öğrencinin dikkatini çekmemektedir. Bu da öğrencinin ilgisini çekmemekte haliyle sıkıcı bir ders ortaya çıkmaktadır.

Örnekler daha çok olmalı içerik geliştirilmeli daha ilgi çekici ve güncel olmalı, daha eğlenceli olmalı.

$\begin{array}{clllc}\text { Sınıf Düzeylerine Uygun Hazırlanmış Olması } & 1 & 1 & \text { Sınıf düzeylerine uygun. } \\ \text { Materyallerin Az Olması } & 1 & 1 & \begin{array}{c}\text { EBA içerisinde konuşma becerisini geliştirmeye } \\ \text { yönelik materyaller kazanımlara oranla daha }\end{array}\end{array}$


EBA'nın Türkçe Öğretim Programı Öğrenme Alanlarını Karşılama Yeterliliğine Yönelik Öğretmen Görüşleri

çok sınırlı, hatta yok denecek kadar az.

\begin{tabular}{|c|c|c|c|}
\hline Geliştirilmesi Gerekli & 1 & 1 & Geliştirilebilir. \\
\hline Metinlerin Anlaşılır Dille Aktarılması & 1 & 1 & $\begin{array}{c}\text { Okuyucunun Türkçeyi anlaşılır ve yavaş yavaş } \\
\text { konuşması öğrencinin İstanbul Türkçesi ile } \\
\text { konuşmasına, konuşurken kullandığı kelimeleri } \\
\text { dikkatli seçmesini sağlıyor. }\end{array}$ \\
\hline Kelimeler İyi Seçilmiş OIması & 1 & 1 & $\begin{array}{c}\text { Okuyucunun Türkçeyi anlaşılır ve yavaş yavaş } \\
\text { konuşması öğrencinin Istanbul Türkçesi ile } \\
\text { konuşmasına, konuşurken kullandığı kelimeleri } \\
\text { dikkatli seçmesini sağlıyor. }\end{array}$ \\
\hline Videolarla Desteklenmesi Gerekliliği & 1 & 1 & $\begin{array}{c}\text { Güncel hayatla daha çok ilişkilendirilmeli ve } \\
\text { videolarla desteklenmelidir. }\end{array}$ \\
\hline İçerikler Farklı Seviyelere Göre Hazırlanmalı & 1 & 1 & $\begin{array}{c}\text { 5. sınıf düzeyinde söz varlığını geliştirmeye } \\
\text { yönelik çocukların seviyesine uygun içerikler } \\
\text { bulunurken 6,7 ve 8. Sınıf seviyesinde konuşma } \\
\text { bölümü içinde söz varlığını geliştirmeye yönelik } \\
\text { içerik bulunmamaktadır. }\end{array}$ \\
\hline $\begin{array}{c}\text { Diksiyon ve Tekerlemelere Yer Verilmesi } \\
\text { Olumlu }\end{array}$ & 1 & 1 & $\begin{array}{l}\text { Konuşma becerilerini geliştirmeye yönelik } \\
\text { diksiyon ve tekerleme gibi çeşitli etkinliklere yer } \\
\text { verilmesini olumlu olarak değerlendiriyorum. }\end{array}$ \\
\hline $\begin{array}{l}\text { Metinlerin Görsellerle Desteklenmesinin } \\
\text { Güzel Oluşu }\end{array}$ & 1 & 1 & $\begin{array}{c}\text { Dinleme becerilerini geliştirmeye yönelik } \\
\text { dinleme metinlerinin görsellerle desteklenerek } \\
\text { dersin daha çok ilgi çekici hale getirilmesini son } \\
\text { derece faydalı olarak görüyorum. }\end{array}$ \\
\hline Metinlerin Yetersiz Oluşu & 1 & 1 & $\begin{array}{c}\text { Mevcut etkinlikleri faydalı buluyorum ancak } \\
\text { metinlerin ve görsellerin yetersiz olduğunu konu } \\
\text { ve seviyeye göre zenginleştirilmesi gerektiğini } \\
\text { düşünüyorum. }\end{array}$ \\
\hline
\end{tabular}

Konuşma becerisine yönelik 43 kod elde edilmiştir. 31 kod olumsuz sayılabilecek nitelikte kodlardan oluşmaktadır. En çok kod sayısına sahip içeriklerin eklenmesi gerekliliği, içeriğin yetersiz oluşuna dair kodlar görüş olarak birbirine çok yakın kodlardır. Bu kodlardan konuşma içeriklerinin yetersiz olduğuna dair bir kanaat oluşturduğunu görmekteyiz. Hemen arkasından gelen içeriklerin faydalı olması ve yeterli olması kodları içeriklerin olumlu nitelikler taşıdığını da göstermektedir. Olumlu nitelikte sayabileceğimiz kod sayısı 12 'dir. Kodlardan ve örnek görüşlerden de anlaşılacağı üzere konuşma içeriklerin yetersiz oluşu daha ağır basmaktadır. 22 çeşit kod olması öğretmenlerin içerik hakkında bilgi sahibi olduklarını göstermektedir. İçerikler hakkında olumlu ve olumsuz görüşlerin bir arada olması öğretmenlerin içeriği sağlıklı bir şekilde değerlendirdiklerinin göstergesidir. 
Dinleme becerilerini geliştirmeye yönelik içeriklerin yeterliliği hakkında öğretmen görüşleri

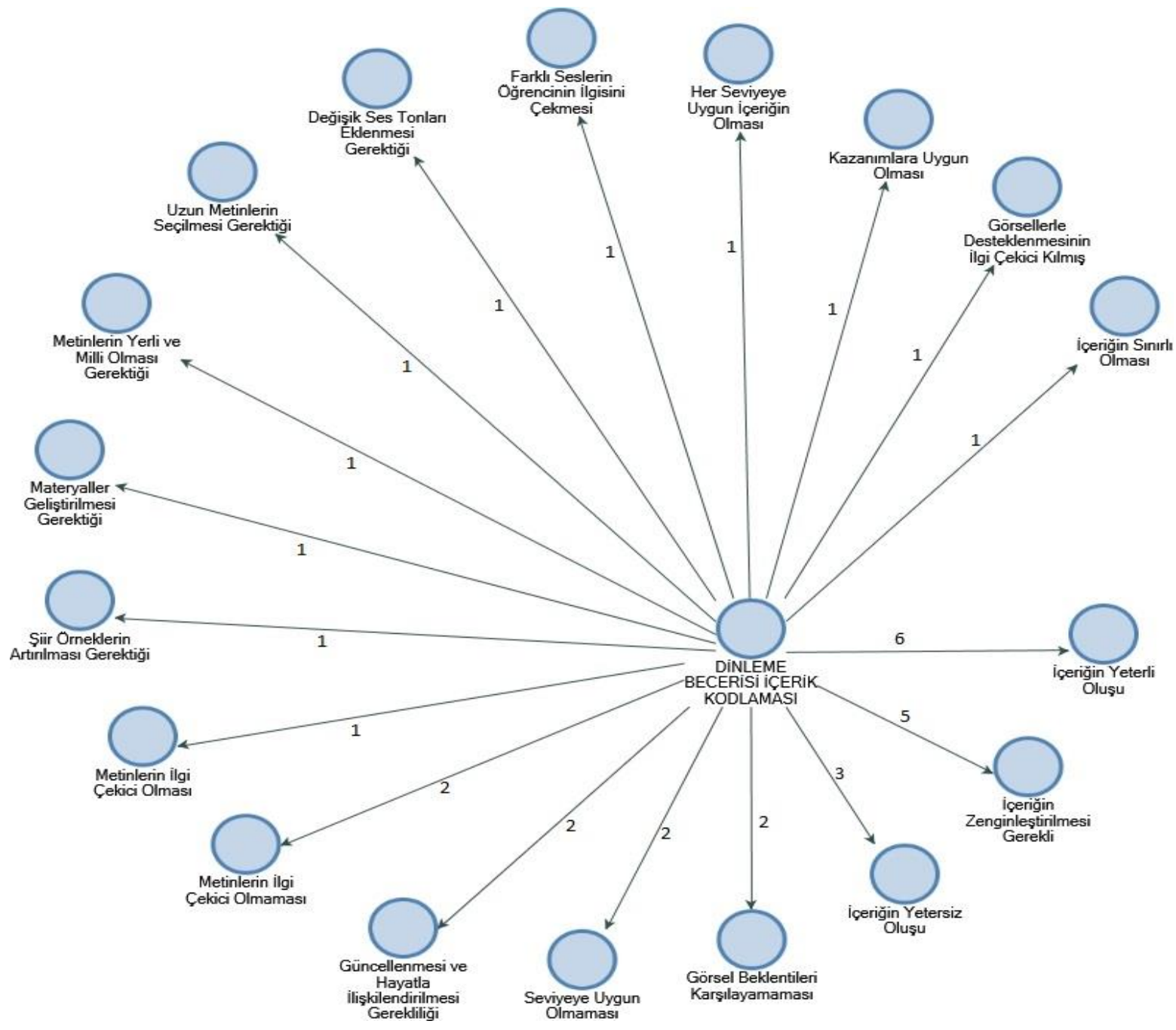

Şekil 2. Dinleme içerikleri kod grafiği

Tablo 4. Dinleme becerisi içeriklerine ait kod tablosu

\begin{tabular}{|c|c|c|c|}
\hline Tema ve Kod Adı & 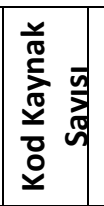 & 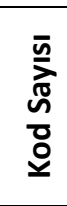 & Örnek Kodlamalar \\
\hline & 20 & 34 & \\
\hline İçeriğin Yeterli Oluşu & 6 & 6 & $\begin{array}{c}\text { *Bu içeriğin istenen hedefe ulaşma adına } \\
\text { yeterli olduğu düşünüyorum. } \\
\text { *Dinlediğini anlama ve çözümleme } \\
\text { konusuyla ilgili yeterli içerik vardır. }\end{array}$ \\
\hline İçeriğin Zenginleştirilmesi Gerekli & 4 & 5 & $\begin{array}{c}\text { Dinleme becerilerini geliştirmeye yönelik } \\
\text { içeriklerin sınırlı olduğunu düşünüyorum. } \\
\text { Temalar doğrultusunda zenginleştirme } \\
\text { yapılmalı. }\end{array}$ \\
\hline İçeriğin Yetersiz Oluşu & 3 & 3 & $\begin{array}{c}\text { Dinleme beceriyle ilgili EBA'ya } \\
\text { baktığımızda dinleme kurallarıyla ilgili } \\
\text { içeriklerin yetersiz olduğunu görüyoruz } \\
\text { ancak dinlediğini anlama ve çözümleme } \\
\text { konusuyla ilgili yeterli içerik vardır. Buna } \\
\text { rağmen dinleme beceriyle ilgili yeterli } \\
\text { içerik vardır diyemeyiz. }\end{array}$ \\
\hline
\end{tabular}


EBA'nın Türkçe Öğretim Programı Öğrenme Alanlarını Karşılama Yeterliliğine Yönelik Öğretmen Görüşleri

\begin{tabular}{|c|c|c|c|}
\hline Seviyeye Uygun Olmaması & 2 & 2 & $\begin{array}{c}\text { Yeterli olabilir yukarıda belirttiğim gibi } \\
\text { dinletilen metinlerin seviyeye uygun ve ilgi } \\
\text { çekici olması gerekir. }\end{array}$ \\
\hline $\begin{array}{l}\text { Güncellenmesi ve Hayatla illişkilendirilmesi } \\
\text { Gerekliliği }\end{array}$ & 2 & 2 & $\begin{array}{c}\text { Güncel hayatla daha çok ilişkilendirilmeli } \\
\text { ve videolarla desteklenmelidir. }\end{array}$ \\
\hline Metinlerin İlgi Çekici Olmaması & 2 & 2 & $\begin{array}{c}\text { Dinleme metinleri biraz daha yerli ve milli } \\
\text { olsun çocukların ilgisini çekecek dinleme } \\
\text { metinleri olsa daha iyi olur. }\end{array}$ \\
\hline Görsel Beklentileri Karşılayamaması & 1 & 1 & $\begin{array}{c}\text { Dinleme esnasında öğrencilerin görsel } \\
\text { beklentileri karşılanmamakta haliyle, } \\
\text { beklentiyi karşılamamaktadır. }\end{array}$ \\
\hline Şiir Örneklerin Artırılması Gerektiği & 1 & 1 & $\begin{array}{c}\text { Dinleme becerilerine yönelik olarak } \\
\text { derslerde öğrencilerime şiir dinletirdim. } \\
\text { Çok ilgilerini çekti şiir örnekleri artırılabilir. }\end{array}$ \\
\hline Materyaller Geliştirilmesi Gerektiği & 1 & 1 & $\begin{array}{l}\text { Derste kullanılacak materyaller mevcut, } \\
\text { ancak geliştirilmeye muhtaç. }\end{array}$ \\
\hline Metinlerin Yerli ve Milli Olması Gerektiği & 1 & 1 & $\begin{array}{c}\text { Dinleme metinleri biraz daha yerli ve milli } \\
\text { olsun çocukların ilgisini çekecek dinleme } \\
\text { metinleri olsa daha iyi olur. }\end{array}$ \\
\hline Uzun Metinlerin Seçilmesi Gerektiği & 1 & 1 & Daha uzun soluklu metinler seçilmeli. \\
\hline Değişik Ses Tonları Eklenmesi Gerektiği & 1 & 1 & $\begin{array}{c}\text { Dinleme öğretmenin sesinden farklı ses } \\
\text { duyan öğrenciler biraz daha ilgiyle } \\
\text { dinlemekte. Yalnız bayan sunucularının } \\
\text { sayısının artırılması değişik ses tonlarının } \\
\text { olması daha iyi olabilir. }\end{array}$ \\
\hline Farklı Seslerin Öğrencinin îlgisini Çekmesi & 1 & 1 & $\begin{array}{c}\text { Dinleme öğretmenin sesinden farklı ses } \\
\text { duyan öğrenciler biraz daha ilgiyle } \\
\text { dinlemekte. Yalnız bayan sunucularının } \\
\text { sayısının artırılması değişik ses tonlarının } \\
\text { olması daha iyi olabilir. }\end{array}$ \\
\hline
\end{tabular}

Dinleme becerileriyle ilgili içeriklere $\begin{array}{rllll}\text { Her Seviyeye Uygun İçeriğin Olması } & 1 & 1 & \begin{array}{c}\text { baktığımızda genelde her sınıf seviyesinde } \\ \text { içerikler mevcuttur. Bu içerikler her sınıf } \\ \text { düzeyindeki kazanımlara uygundur. }\end{array}\end{array}$

\begin{tabular}{llllc}
\hline Kazanımlara Uygun Olması & 1 & 1 & $\begin{array}{c}\text { Bu içerikler her sınıf düzeyindeki } \\
\text { kazanımlara uygundur. }\end{array}$ \\
\hline Görsellerle Desteklenmesinin İlgi Çekici Olması & 1 & 1 & $\begin{array}{c}\text { Dinleme becerilerini geliştirmeye yönelik } \\
\text { dinleme metinlerinin görsellerle } \\
\text { desteklenerek dersin daha çok ilgi çekici } \\
\text { hale getirilmesini son derece faydalı } \\
\text { olarak görüyorum. }\end{array}$ \\
\hline İçeriğin Sınırlı Olması & 1 & 1 & $\begin{array}{c}\text { Dinleme becerilerini geliştirmeye yönelik } \\
\text { içeriklerin sınırlı olduğunu düşünüyorum. } \\
\text { Temalar doğrultusunda zenginleştirme } \\
\text { yapılmalı. }\end{array}$
\end{tabular}

Görüşme formlarından 16 farklı kod elde edilmiştir. 34 kod sayısından 21'i olumsuz sayılabilecek niteliktedir. Bu sayılar dinleme içeriklerinin yetersiz olduğunu göstermektedir. İçeriğin Zenginleştirilmesi Gerekli, İçeriğin Yetersiz Oluşu, Görsel Beklentileri Karşılayamaması, Seviyeye 
Uygun Olmaması, Güncellenmesi ve Hayatla Ilişsilendirilmesi Gerekliliği, Metinlerin ilgi Çekici Olmaması gibi kodlar olumsuz nitelikte sayılabilecek kodlardır. 34 kod sayısından 13'ü olumlu sayılabilecek nitelikte kodlardır. İçeriğin Yeterli Oluşu 6 kez kodlamayla en fazla kod sayısına sahip koddur. Dinleme bölümünde olumlu nitelikte bir kodun fazla kod sayısına sahip olması dinleme içeriklerinin konuşmaya göre daha iyi olduğunun göstergesidir. Metinlerin İlgi Çekici Olması, Farklı Seslerin Öğrencinin İlgisini Çekmesi, Her Seviyeye Uygun İçeriğin Olması, Kazanımlara Uygun Olması, Görsellerle Desteklenmesinin İlgi Çekici KıImış olumlu sayılabilecek kodlardandır. Bu kodlar içeriğin iyi özellikler de taşıdığını ortaya koymaktadır.

Okuma becerilerini geliştirmeye yönelik içeriklerin yeterliliği hakkında öğretmen görüşleri

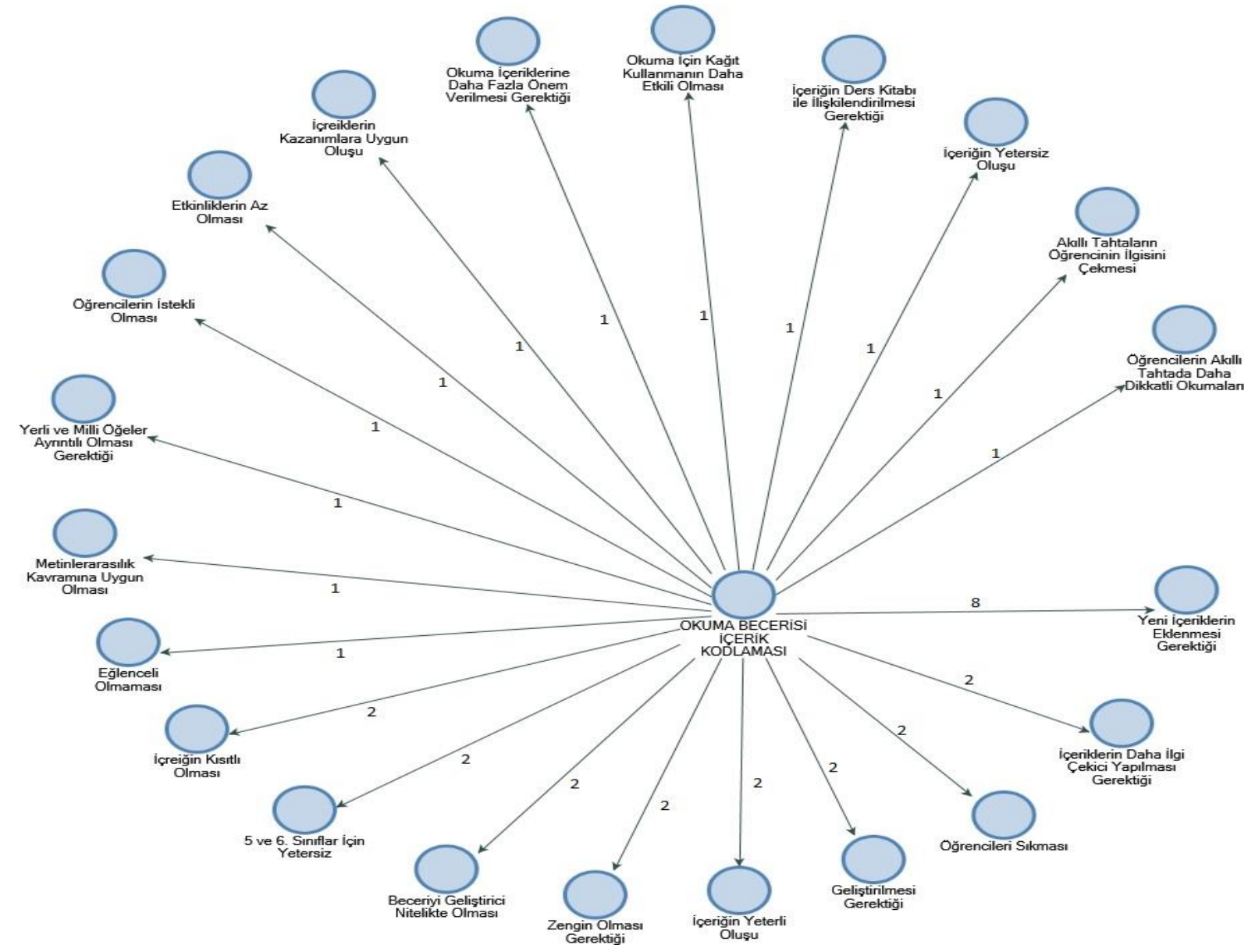

Şekil 3. Okuma içerikleri kod grafiği

Tablo 5. Okuma becerisi içeriklerine ait kod tablosu

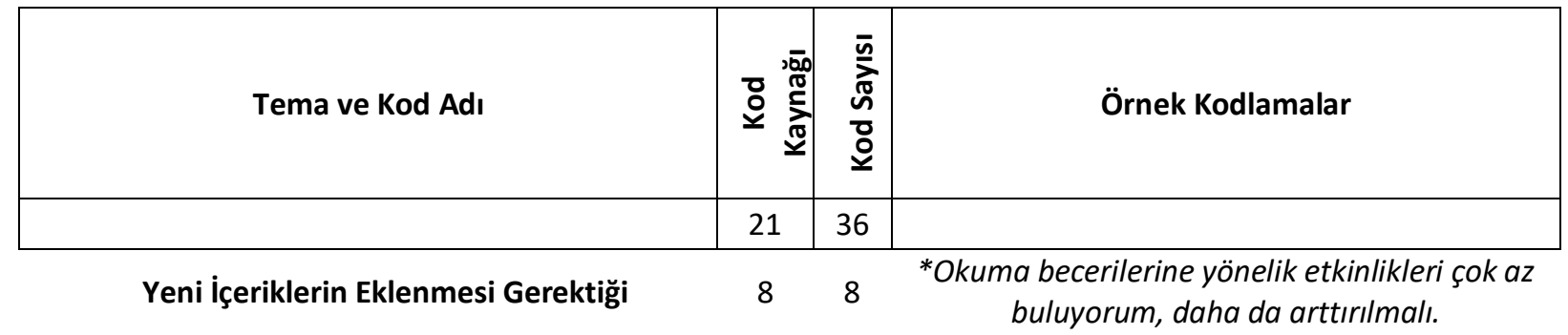


EBA'nın Türkçe Öğretim Programı Öğrenme Alanlarını Karşılama Yeterliliğine Yönelik Öğretmen Görüşleri

\begin{tabular}{|c|c|c|c|}
\hline & & & $\begin{array}{c}\text { *Örnek okuma metinleri konulabilir hızlı ve } \\
\text { anlaşılır okuma yapmak için ders sunumları } \\
\text { konabilir. }\end{array}$ \\
\hline İçeriklerin Daha İlgi Çekici Yapılması Gerektiği & 2 & 2 & $\begin{array}{c}\text { e-kitap yükleme daha ilgi çekici hale } \\
\text { getirilebilir. }\end{array}$ \\
\hline Öğrencileri Sıkması & 2 & 2 & $\begin{array}{c}\text { Hızlı okuma konusunda kişisel gelişim } \\
\text { videolarından yararlandım. Öğrencilerin } \\
\text { sıkıldıklarını fark ettim. Daha eğlenceli hale } \\
\text { getirilebilir. }\end{array}$ \\
\hline Geliştirilmesi Gerektiği & 2 & 2 & $\begin{array}{c}\text { Okuma becerilerinin geliştirilmesi gerektiğini } \\
\text { düşünüyorum. Ok takipli büyük puntolu } \\
\text { metinler eklenirse iyi olur. }\end{array}$ \\
\hline İçeriğin Yeterli Oluşu & 2 & 2 & $\begin{array}{c}\text { Okuma becerilerini geliştirmeye yönelik } \\
\text { materyaller yeterli diyebilirim. Hem ders için } \\
\text { hem disiplinler arası geçiş gereği diğer } \\
\text { derslerle ilgili yardımcı metinlere } \\
\text { ulaşılabilmektedir. }\end{array}$ \\
\hline Zengin Olması Gerektiği & 2 & 2 & Okuma metinleri daha zengin olsa .... \\
\hline Beceriyi Geliştirici Nitelikte OIması & 2 & 2 & $\begin{array}{c}\text { Okuma becerilerini geliştirebilirler. Çünkü akıllı } \\
\text { tahtalar okuma öğrencinin daha çok ilgisini } \\
\text { çekmektedir. }\end{array}$ \\
\hline 5 ve 6. Sınıflar İçin Yetersiz & 2 & 2 & $\begin{array}{c}\text { Okuma becerileriyle ilgili 5. Sınıf içerikleri } \\
\text { yeterli olmasa da diğer sınıf düzeylerinde yeteri } \\
\text { kadar içerik vardır. }\end{array}$ \\
\hline İçeriğin Kısıtlı Olması & 1 & 1 & Okuma becerileri tamamen kısıtıdır. \\
\hline Eğlenceli OImaması & 1 & 1 & $\begin{array}{c}\text { Hızlı okuma konusunda kişisel gelişim } \\
\text { videolarından yararlanıyoruz. Öğrenciler biraz } \\
\text { sıkıldılar daha iyi eğlenceli ve canlı videolar } \\
\text { olmalı. }\end{array}$ \\
\hline Metinler Arasılık Kavramına Uygun Olması & 1 & 1 & $\begin{array}{c}\text { Özellikle de ders gereği Sosyal Bilgiler ile ilgili } \\
\text { bağlantılı metinlere disiplinler arası geçişle } \\
\text { ulaşılabilmektedir. }\end{array}$ \\
\hline Yerli ve Milli Öğeler Ayrıntılı Olması Gerektiği & 1 & 1 & Yeterli, kültür öğelerimiz daha detaylı verilmeli. \\
\hline Öğrencilerin İstekli Olması & 1 & 1 & $\begin{array}{c}\text { Okuma becerilerini geliştiriyor çocuklar akıllı } \\
\text { tahtalarda okumak için istekliler, okurken } \\
\text { dikkatli davranıyorlar. }\end{array}$ \\
\hline Etkinliklerin Az Olması & 1 & 1 & $\begin{array}{c}\text { Okuma becerilerine yönelik etkinlikleri çok az } \\
\text { buluyorum, daha da arttırılmalı. }\end{array}$ \\
\hline İçeriklerin Kazanımlara Uygun Oluşu & 1 & 1 & $\begin{array}{c}\text { Okuma becerileriyle ilgili içerikler her sınıf } \\
\text { düzeyindeki kazanımlara uygundur. }\end{array}$ \\
\hline $\begin{array}{c}\text { Okuma İçeriklerine Daha Fazla Önem } \\
\text { Verilmesi Gerektiği }\end{array}$ & 1 & 1 & $\begin{array}{c}\text { Ülkemiz genelinde yapılan sınavlara } \\
\text { baktığımızda bu sınavlarda okuma ve } \\
\text { anlamaya yönelik soruların artması bu içeriğe } \\
\text { daha fazla önem verilmesi gerektiğini kanıtlar } \\
\text { niteliktedir. }\end{array}$ \\
\hline $\begin{array}{c}\text { Okuma İçin Kâğıt Kullanmanın Daha Etkili } \\
\text { Olması }\end{array}$ & 1 & 1 & $\begin{array}{c}\text { Okuma becerilerinde kâğıt kullanımının daha } \\
\text { etkili olacağını düşünüyorum. }\end{array}$ \\
\hline $\begin{array}{c}\text { İçeriğin Ders Kitabı ile illişkilendirilmesi } \\
\text { Gerektiği }\end{array}$ & 1 & 1 & Bu bağlamda ders kitabı ile ilişkilendirilmeli. \\
\hline İçeriğin Yetersiz Oluşu & 1 & 1 & $\begin{array}{c}\text { İ̧eriklerin yetersiz olduğunu düşünüyorum, } \\
\text { zenginleştirilmeli. }\end{array}$ \\
\hline Akıllı Tahtaların Öğrencinin İlgisini Çekmesi & 1 & 1 & $\begin{array}{l}\text { Okuma becerilerini geliştirebilirler. Çünkü akıllı } \\
\text { tahtalar okuma öğrencinin daha çok ilgisini }\end{array}$ \\
\hline
\end{tabular}


çekmektedir.

\section{Öğrencilerin Akıllı Tahtada Daha Dikkatli Okumaları}
Okuma becerilerini geliştiriyor çocuklar akıllı tahtalarda okumak için istekliler, okurken dikkatli davranıyorlar.

Okuma becerilerine yönelik 21 farklı kod bulunmaktadır. Kod sayısı ise 36'dır. Kodlardan 26'sı olumsuz nitelikte kodlardır. Yeni İçeriklerin Eklenmesi Gerektiği, İçeriklerin Daha İlgi Çekici Yapılması Gerektiği, Öğrencileri Sıkması, Geliştirilmesi Gerektiği, Zengin Olması Gerektiği, 5 ve 6. Sınıflar İ̧̧in Yetersiz, İçeriğin Kısıtlı Olması, Eğlenceli Olmaması en çok kullanılan olumsuz kodlar arasındadır. Olumsuz kod sayısının çok fazla olması okuma içeriklerinin yetersiz olduğunu göstermektedir. Yerli ve Milli Öğeler Ayrıntıı Olması Gerektiği, Okuma İçin Kâğıt Kullanmanın Daha Etkili Olması, İçeriğin Ders Kitabı ile Illişkilendirilmesi Gerektiği, Metinler Arasılık Kavramına Uygun Olması kodları içeriklerin ayrıntılı bir şekilde değerlendirildiğini göstermektedir. Kodlardan 10 tanesi olumlu sayılabilecek nitelikte kodlardır. Olumlu kod sayısının az olması içeriklerin tam anlamıyla yeterli olmadığını göstermektedir.

Yazma becerilerini geliştirmeye yönelik içeriklerin yeterliliği hakkında öğretmen görüşleri

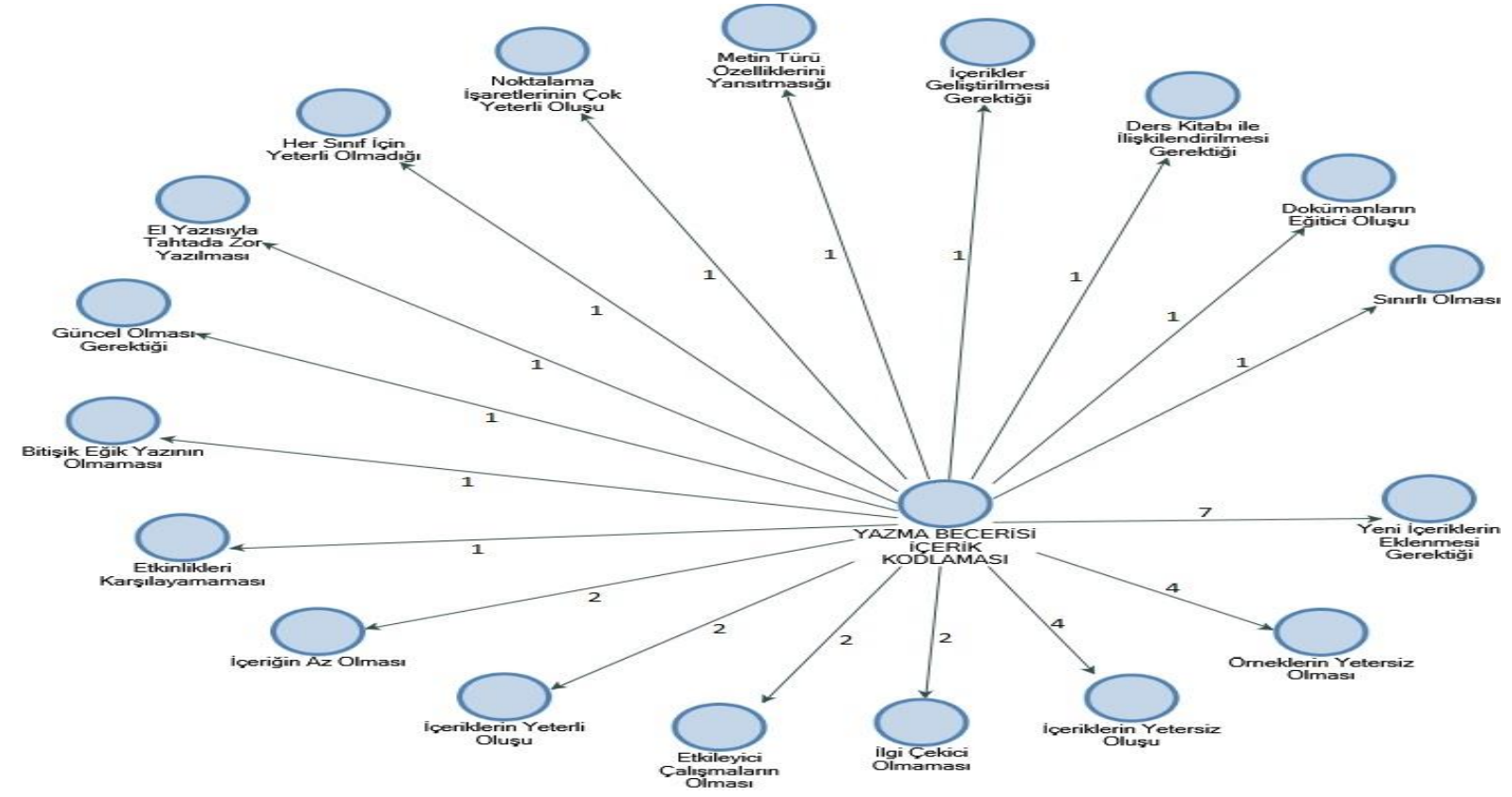

Şekil 4. Yazma içerikleri kod grafiği

Tablo 6. Yazma becerisi içeriklerine ait kod tablosu

\begin{tabular}{|c|c|c|c|}
\hline Tema ve Kod Adı & 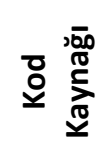 & 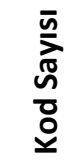 & Örnek Kodlamalar \\
\hline & 22 & 35 & \\
\hline
\end{tabular}

*Ders kitabı ile iliş̧ilendirilerek etkinlikler çeşitlendirilmelidir.

*Yazma becerilerini geliştirmek için içerik artırılabilir. 
EBA'nın Türkçe Öğretim Programı Öğrenme Alanlarını Karşılama Yeterliliğine Yönelik Öğretmen Görüşleri

\begin{tabular}{|c|c|c|c|}
\hline Örneklerin Yetersiz Olması & 4 & 4 & $\begin{array}{l}\text { Yazma becerilerini geliştirmeye dönük } \\
\text { alıştırma, örnek uygulamaları yetersizdir. }\end{array}$ \\
\hline İçeriklerin Yetersiz Oluşu & 4 & 4 & $\begin{array}{l}\text { *Yazmayla ilgili kuralların içerik bakımından } \\
\text { yeterli olması durumunda çok faydalı olabilir. } \\
\text { *Yazma becerileri açısından yetersiz. }\end{array}$ \\
\hline İlgi Çekici Olmaması & 2 & 2 & $\begin{array}{c}\text { Daha çok ilgi çekici konular hakkında olmalı } \\
\text { ve günümüz çocuklarının ilgi alanları ve } \\
\text { problemleri üzerine olmalı. }\end{array}$ \\
\hline Etkileyici Çalışmaların Olması & 2 & 2 & $\begin{array}{c}\text { Bu içerikte öğrencilerin yazma becerilerine } \\
\text { yönelik etkileyici çalışmalar vardır. Yazma } \\
\text { becerilerini geliştirmiştir. }\end{array}$ \\
\hline İçeriklerin Yeterli Oluşu & 2 & 2 & $\begin{array}{l}\text { Dil bilgisi kazanımlarından sonra materyal } \\
\text { bulma konusunda sıkıntı yaşamadığımız bir } \\
\text { kazanım, yeterli olduğu kanısındayım. }\end{array}$ \\
\hline İçeriğin Az Olması & 2 & 2 & $\begin{array}{c}\text { Yazma becerisine yönelik çalışmalar yok } \\
\text { denecek kadar az. }\end{array}$ \\
\hline Etkinlikleri Karşılayamaması & 1 & 1 & $\begin{array}{c}\text { Bu yüzden Türkçenin ders etkinliklerine } \\
\text { karşılamamaktadır. }\end{array}$ \\
\hline Bitişik Eğik Yazının Olmaması & 1 & 1 & $\begin{array}{l}\text { Yazmada ikilemde kalıyorum bitişik yazı } \\
\text { istiyor ama örneklerde bitişik yazı yok. }\end{array}$ \\
\hline Güncel Olması Gerektiği & 1 & 1 & $\begin{array}{c}\text { Daha çok ilgi çekici konular hakkında olmalı } \\
\text { ve günümüz çocuklarının ilgi alanları ve } \\
\text { problemleri üzerine olmalı. }\end{array}$ \\
\hline
\end{tabular}

\begin{tabular}{|c|c|c|c|}
\hline El Yazısıyla Tahtada Zor Yazılması & 1 & 1 & $\begin{array}{c}\text { El yazısı ile yazmaya çalışan öğrenciler } \\
\text { tahtaya yazmakta zorlanıyor. El yazısı ile } \\
\text { yazdığını okuyamıyor. }\end{array}$ \\
\hline Her Sınıf İçin Yeterli Olmadığı & 1 & 1 & $\begin{array}{c}\text { Yazma becerilerine yönelik 5. Sınıfta içerikler } \\
\text { yetersiz olmasına rağmen diğer sınıflarda } \\
\text { yeterlidir. }\end{array}$ \\
\hline Noktalama İşaretlerinin Çok Yeterli Oluşu & 1 & 1 & $\begin{array}{l}\text { Yazma becerilerine yönelik içeriklere } \\
\text { baktığımızda özellikle noktalama işaretleri } \\
\text { her sınıf düzeyine uygun olarak verilmiş. Her } \\
\text { sınıf düzeyine uygun örnekler verilmiş. }\end{array}$ \\
\hline Metin Türü Özelliklerini Yansıtmadığı & 1 & 1 & $\begin{array}{c}\text { Yazma becerilerine yönelik içeriklerde tüm } \\
\text { metin türlerinin özelliklerine uygun içeriğin } \\
\text { olmadığını fark ediyoruz. }\end{array}$ \\
\hline İçerikler Geliştirilmesi Gerektiği & 1 & 1 & $\begin{array}{l}\text { Dolayısıyla yazma becerisi ile ilgili içeriğin } \\
\text { geliştirilmesi gerektiğini düşünüyorum. }\end{array}$ \\
\hline Ders Kitabı ile İlişkilendirilmesi Gerektiği & 1 & 1 & $\begin{array}{c}\text { Ders kitabı ile ilişkilendirilerek etkinlikler } \\
\text { çeşitlendirilmelidir. }\end{array}$ \\
\hline
\end{tabular}




\begin{tabular}{ccccc}
\hline Dokümanların Eğitici Oluşu & 1 & 1 & $\begin{array}{c}\text { içerik ve dokümanlar eğitici ancak sınırlı } \\
\text { olduğunu düşünüyorum. }\end{array}$ \\
\hline Sınırlı Olması & 1 & 1 & $\begin{array}{c}\text { Içerik ve dokümanlar eğitici ancak sınırlı } \\
\text { olduğunu düşünüyorum. }\end{array}$ \\
\hline
\end{tabular}

Yazma becerisi ile ilgili 18 farklı kod elde edilmiştir. Toplam 35 kod sayısı bulunmaktadır. Olumsuz sayılabilecek nitelikte 28 kod bulunmaktadır. Sadece 7 kod olumlu sayılabilecek nitelikte kodlardan oluşmaktadır. Kod sayılarından ve öğretmen görüşlerinden hareketle bu bölümüz diğer bölümlere göre daha yetersiz olduğu görülmektedir. Bitişik Eğik Yazının Olmaması, Güncel Olması Gerektiği, El Yazısıyla Tahtada Zor Yazılması, Her Sınıf İçin Yeterli Olmadığı, Metin Türü Özelliklerini Yansıtmadığı, Ders Kitabı ile İlişkilendirilmesi Gerektiği, Etkileyici Çalışmaların Olması, Noktalama İşaretlerinin Çok Yeterli Oluşu, Dokümanların Eğitici Oluşu kodları yazma içeriklerine yönelik farklı tespitleri gösteren kodlardır.

Dil bilgisi becerilerini geliştirmeye yönelik içeriklerin yeterliliği hakkında öğretmen görüşleri

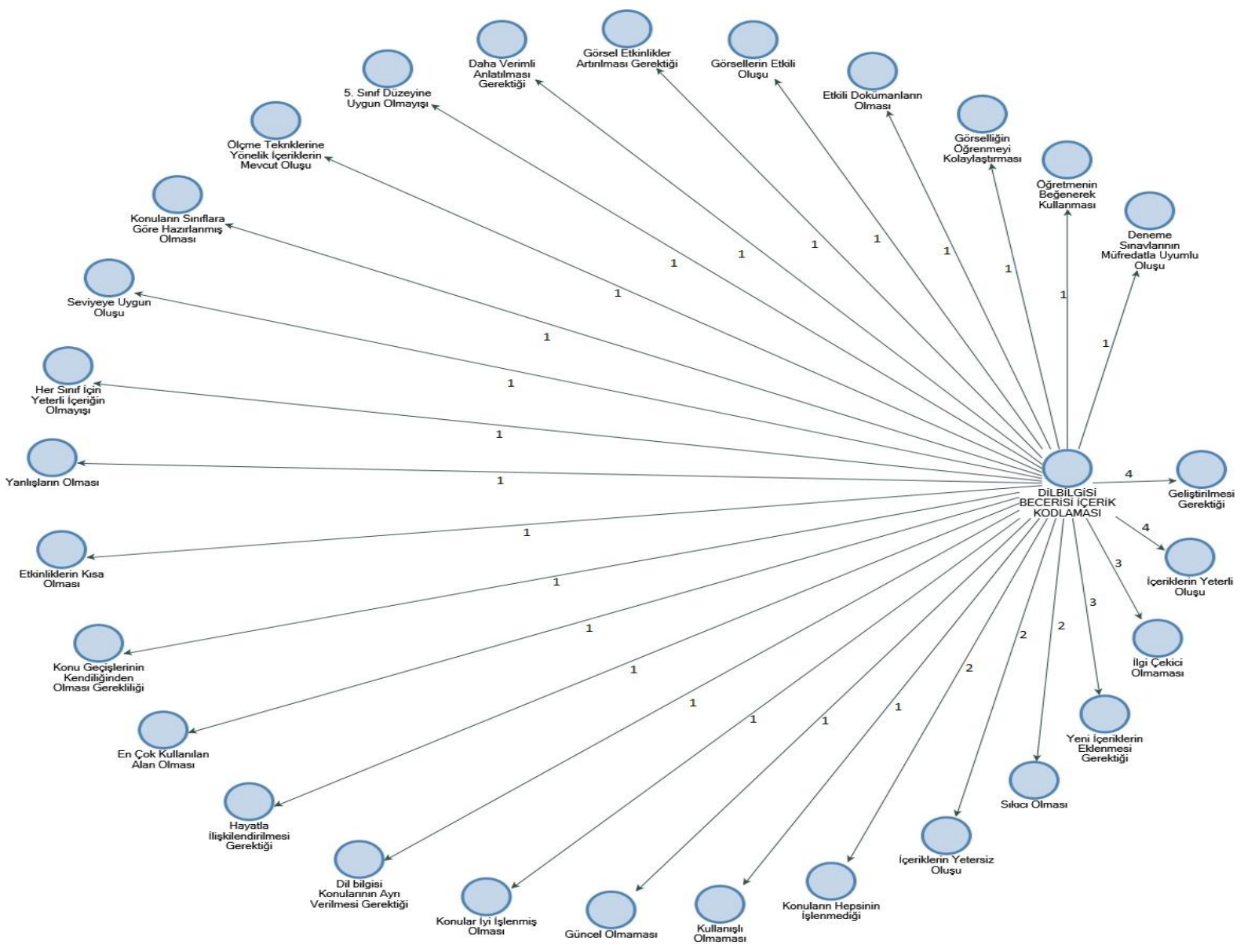

Şekil 5. Dil bilgisi içerikleri kod grafiği 
Tablo 7. Dil bilgisi içeriklerine ait kod tablosu

\begin{tabular}{|c|c|}
\hline Tema ve Kod Adı & 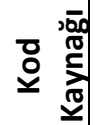 \\
\hline & 23 \\
\hline
\end{tabular}

Geliştirilmesi Gerektiği

4

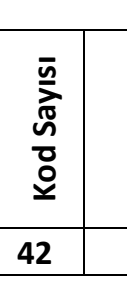

Örnek Kodlamalar

*Tüm konulara yönelik etkinlik test vb çalışmaların henüz yeterli olmadığını ve bu içeriğin de geliştirilmesi gerektiğini düşünüyorum. 4

*EBA'nın dil bilgisi bölümü daha etkileyici olabilirdi. içerik geliştirilirse iyi olur.

\begin{tabular}{|c|c|c|c|}
\hline İçeriklerin Yeterli Oluşu & 4 & 4 & $\begin{array}{l}\text { En fazla materyal bulabildiğimiz kazanım dil bilgisi } \\
\text { konularıdır, çok fazla materyale ulaşabilmek mümkün. }\end{array}$ \\
\hline İlgi Çekici Olmaması & 3 & 3 & $\begin{array}{c}\text { Dil bilgisi konuları tamamen düz anlatım şeklinde } \\
\text { verilmesinden kaynaklı olarak sıkıcı olmaktadır. }\end{array}$ \\
\hline Yeni İçeriklerin Eklenmesi Gerektiği & 3 & 3 & $\begin{array}{l}\text { En çok dil bilgisi becerilerine örnek verilmiş ama } \\
\text { yenileri eklenebilir. }\end{array}$ \\
\hline Sıkıcı Olması & 2 & 2 & $\begin{array}{l}\text { Dil bilgisi konuları tamamen düz anlatım şeklinde } \\
\text { verilmesinden kaynaklı olarak sıkıcı olmaktadır. }\end{array}$ \\
\hline İçeriklerin Yetersiz Oluşu & 2 & 2 & $\begin{array}{l}\text { Dil bilgisi konularını ve anlatımını yetersiz ve sıkıcı } \\
\text { buluyorum. }\end{array}$ \\
\hline Konuların Hepsinin İşlenmediği & 2 & 2 & Bütün dil bilgisi konuları işlenmelidir. \\
\hline Kullanışlı OImaması & 1 & 1 & $\begin{array}{l}\text { Verilen araştırmalar da uygulama açısından kullanışlı } \\
\text { değildir. }\end{array}$ \\
\hline Güncel Olmaması & 1 & 1 & Daha güncel olmalı. \\
\hline Konular İyi İşlenmiş OIması & 1 & 1 & Konuların lyi anlatıldığını düşünüyorum. \\
\hline $\begin{array}{c}\text { Dil bilgisi Konularının Ayrı Verilmesi } \\
\text { Gerektiği }\end{array}$ & 1 & 1 & Metinlerde dil bilgisi konusu net olarak verilmeli. \\
\hline Hayatla İlişkilendirilmesi Gerektiği & 1 & 1 & $\begin{array}{c}\text { Geliştirilebilir, içeriklerin anlatılışı ilgi çekici ve güncel } \\
\text { hayatla ilişkilendirilmeli. }\end{array}$ \\
\hline En Çok Kullanılan Alan Olması & 1 & 1 & $\begin{array}{c}\text { En çok dil bilgisi kullanıyoruz. Konu geçişlerinin } \\
\text { birbiriyle bağlantısı yani konu geçişlerinin } \\
\text { kendiliğinden olması gerekli örneklerinin çoğaltılması } \\
\text { daha iyi olur. }\end{array}$ \\
\hline $\begin{array}{l}\text { Konu Geçişlerinin Kendiliğinden } \\
\text { Olması Gerekliliği }\end{array}$ & 1 & 1 & $\begin{array}{c}\text { Konu geçişlerinin birbiriyle bağlantısı yani konu } \\
\text { geçişlerinin kendiliğinden olması gerekli örneklerinin } \\
\text { çoğaltılması daha iyi olur. }\end{array}$ \\
\hline Etkinliklerin Kısa Olması & 1 & 1 & $\begin{array}{c}\text { Dil bilgisi yanlışları çok fazla düzeltilmesi gerekir. } \\
\text { Etkinlikler kısa tutulmuş. }\end{array}$ \\
\hline Yanlışların Olması & 1 & 1 & $\begin{array}{c}\text { Dil bilgisi yanlışları çok fazla düzeltilmesi gerekir. } \\
\text { Etkinlikler kısa tutulmuş. }\end{array}$ \\
\hline Her Sınıf İçin Yeterli İçeriğin Olmayışı & 1 & 1 & $\begin{array}{l}\text { Dil bilgisi becerilerine yönelik 5. Sınıfta içerikler } \\
\text { yetersiz olmasına rağmen diğer sınıflarda yeterlidir. }\end{array}$ \\
\hline Seviyeye Uygun Oluşu & 1 & 1 & $\begin{array}{c}\text { Dil bilgisi konuları ve anlatımları her sınıf düzeyine } \\
\text { göre uygun seçilmiş. }\end{array}$ \\
\hline $\begin{array}{c}\text { Konuların Sınıflara Göre Hazırlanmış } \\
\text { Olması }\end{array}$ & 1 & 1 & $\begin{array}{l}\text { Hangi sınıfta hangi dil bilgisi konuları varsa ona göre } \\
\text { içerikler hazırlanmış. }\end{array}$ \\
\hline $\begin{array}{l}\text { Ölçme Tekniklerine Yönelik } \\
\text { İçeriklerin Mevcut Oluşu }\end{array}$ & 1 & 1 & $\begin{array}{c}\text { Çoktan seçmeli veya eşleştirme gibi farklı ölçme } \\
\text { metotlarına göre de içerikler mevcut. }\end{array}$ \\
\hline 5. Sınıf Düzeyine Uygun Olmayışı & 1 & 1 & $\begin{array}{c}\text { Dil bilgisi ile ilgili olarak içeriklerin özellikle 5. sınıflarda } \\
\text { yeterli olmadığını fark ediyorum. }\end{array}$ \\
\hline Daha Verimli Anlatılması Gerektiği & 1 & 1 & $\begin{array}{c}\text { Dil Bilgisi çalışmaları daha çok örnekler üzerinden ve } \\
\text { daha verimli anlatılmalı diyalogları diyaloglarla }\end{array}$ \\
\hline
\end{tabular}




\begin{tabular}{|c|c|c|c|}
\hline & & & geliştirilmelidir \\
\hline $\begin{array}{l}\text { Görsel Etkinlikler Artırılması } \\
\text { Gerektiği }\end{array}$ & 1 & 1 & Dil bilgisi öğretiminde görsel etkinlikler artırılmalı. \\
\hline Görsellerin Etkili Oluşu & 1 & 1 & $\begin{array}{c}\text { Dil bilgisinde konu anlatımları ve görsel } \\
\text { dokümanların etkili olduğunu düşünüyorum. }\end{array}$ \\
\hline Etkili Dokümanların Olması & 1 & 1 & $\begin{array}{c}\text { Dilbilgisinde konu anlatımları ve görsel } \\
\text { dokümanların etkili olduğunu düşünüyorum. }\end{array}$ \\
\hline $\begin{array}{l}\text { Görselliğin Öğrenmeyi } \\
\text { Kolaylaştırması }\end{array}$ & 1 & 1 & $\begin{array}{l}\text { Akıllı tahta öğrencinin ilgisini görsel olarak çekmesi } \\
\text { öğrencinin zihninde daha kalıcı olması gerçeğini } \\
\text { unutmazsak faydalı olur inancını taşıyorum. }\end{array}$ \\
\hline Öğretmenin Beğenerek Kullanması & 1 & 1 & EBA'nın testlerini beğenerek kullanıyorum. \\
\hline $\begin{array}{l}\text { Deneme Sınavlarının Müfredatla } \\
\text { Uyumlu Oluşu }\end{array}$ & 1 & 1 & $\begin{array}{c}\text { Deneme sınavlarının gerçek sınavlarla çok uyumlu } \\
\text { olduğunu düşünüyorum. EBA'daki sınavlarının } \\
\text { okullarda yapılan sınavlarla uyumlu görmekteyim ve } \\
\text { kullanıyorum }\end{array}$ \\
\hline
\end{tabular}

Dil bilgisi bölümüne yönelik 28 farklı kodlama yapılmıştır. Toplam 42 kod sayısı elde edilmiştir. Bu kodlardan 27 tanesi olumsuz, 15 tanesi olumlu sayılabilecek nitelikte kodlardan oluşmaktadır. Dilbilgisi bu yönüyle diğer alanlara göre daha iyi bir içeriğe sahiptir diyebiliriz. Bu alanda çok çeşitli kodların çıkması dil bilgisi alanın çok kullanıldığını göstermektedir. Bu durum "En çok dil bilgisi kullanıyoruz. Konu geçişlerinin birbiriyle bağlantısı yani konu geçişlerinin kendiliğinden olması gerekli örneklerinin çoğaltılması daha iyi olur. " görüşüyle de ortaya konulmuştur.

Kaynak temelli kodlama

Nvivo 11 programı kodlamaları verileri olumlu ve olumsuz şekilde sınıflayabilecek bir özelik sunmaktadır. Bu özellik kodlamaların genel görüntüsünü daha açık bir şekilde ortaya koyabilecek niteliktedir.

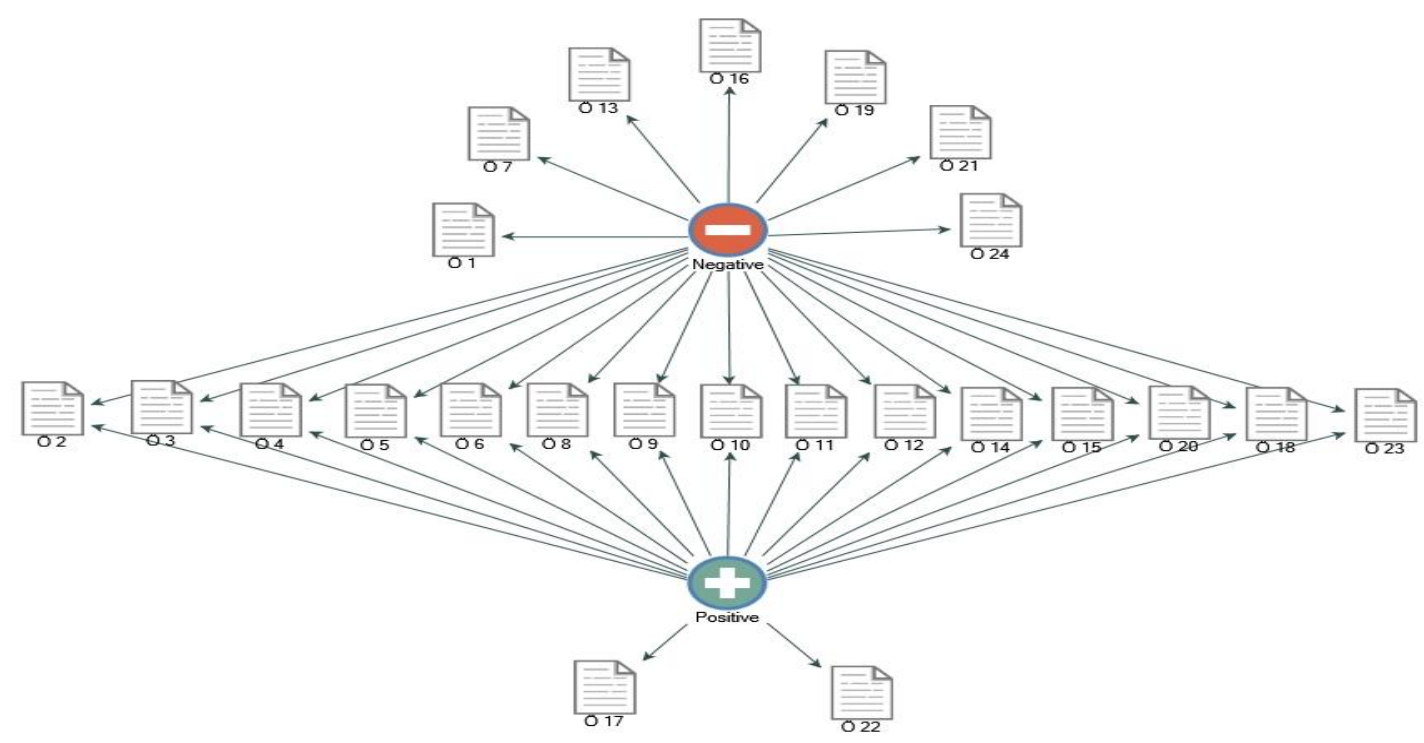

Şekil 6. Kaynak temelli kod grafiği

Araştırma için 24 kaynaktan kodlama yapılmıştır. Öğretmenlerden 7 tanesinin görüşü tamamen olumsuz yöndedir, 2 öğretmenin görüşü ise tamamen olumlu yöndedir, 15 öğretmenin 
görüşü ise hem olumlu hem de olumsuz görüşlerden oluşmuştur. Bu tablodan EBA içeriklerinin hem olumlu hem de olumsuz özellikte içeriklere sahip olduğu, ancak olumsuz görüşlerin daha ağır bastı̆̆ı görülmektedir. 15 öğretmenin hem olumlu hem olumsuz görüş belirtmesi görüşlerin objektifliğini ortaya koymaktadır.

\section{Tartışma ve Sonuç}

Bulgularda Türkçe dersi temel becerilerine yönelik EBA içeriklerin yeterli olmadığına dair görüşlerin daha fazla olduğu görülmektedir. Bunun yanında içeriklerin yeterli olduğuna dair görüşler de az değildir. İçeriklere yönelik olumlu görüşlerin olması EBA Türkçe içeriklerinin belli bir oranda amacına ulaştığının göstergesidir. Bu çalışmanın bulguları ile diğer çalışmaların sonuçları karşılaştıııldığında hem örtüşen hem de çelişen yanların bulunduğunu görmekteyiz.

Aktay ve Keskin (2016) EBA'nın eğitsel bakımdan birçok özellik sunduğu, EBA içerisinde yer alan özellik ve içeriklere bakıldığında, ders, içerik, yarışma, uygulamalar, EBA dosya, e-kurs gibi eğitsel içeriklerin yer aldığı; Tüysüz ve Çümen (2016) öğrencilerin EBA web sitesinin konuları pekiştirmede, sınavlara hazırlık ve konu tekrarı yapmada faydalı bir site olduğu; Aydınözü, Sözcü ve Akbaş (2016) EBA ders uygulamasının öğrencilerin başarısı üzerinde kısmen de olsa olumlu katkı sağladığı; Altın ve Kalelioğlu (2015) etkileşimli tahtanın derslerde verimli kullanıldığı ve etkileşimli tahtadan memnun oldukları; Ağır (2014) öğretmenlerin öğrenciler için de yararlı olduğunu ifade ettikleri; Dursun, Kuzu, Kurt, Güllüpınar ve Gültekin (2013) projeyle birlikte gelen yeniliklerin, dersleri zenginleştireceği, derslere olan ilginin artmasına yardımcı olacağı ve etkili öğrenmenin gerçekleşmesine katkı sağlayacağı; Demircioğlu ve Yadigaroğlu (2014) sınıflara kurulan akıllı tahtaların öğretmenlere ve öğrencilere fayda sağladığı sonuçlarına ulaşmışlardır. EBA' ya yönelik yapılan bu araştırma sonuçları ile bu çalışmadaki içeriğin yeterli olduğu yönündeki olumlu görüşler paralellik göstermektedir. Aynı zamanda olumsuz görüşler ile de çelişmektedir. Diğer araştırmaların sonuçları da göz önünde bulundurulduğunda EBA içeriklerinin kısmen yeterli olduğu ve Türkçe dersine katkıda bulunduğu söylenebilir.

Demircioğlu ve Yadigaroğlu (2014) öğretmenlerin EBA içeriklerinin zenginleştirilmesi gerektiği; Altın ve Kalelioğlu (2015) etkileşimli tahta ve tablet PC'lerdeki içeriklerin yetersiz olduğu; Eren ve Avcı (2016) öğretmenlerin genel olarak e-içerik ihtiyaçlarının olduğu; Pamuk, Çakır, Ergün, Yılmaz ve Ayas (2013) sınıf yönetimi yazılımının kullanılamadığı, e-içeriklerin ve z-kitapların yetersiz olduğu; Dursun, Kırbaş ve Yüksel (2015) EBA'nın materyal sağlama konusunda yetersiz kaldığı ve EBA' da bulunan materyallerin içerikten çok görsel ağırlıklı olması nedeniyle materyallerin kalitesini düşürdüğü; Aktaş, Özmen ve Türkan (2013) etkileşimli tahtaların amacına uygun ve verimli bir şekilde kullanılması yeni içeriklerin hazırlanması ve sayılarının arttırılması gerektiği; Sevimli ve Kul (2015) e- 
içeriğin tamamlanması sürecinde ders kitaplarından etkili olarak yararlanılabilmesi için teknolojinin kullanılabilir olduğu etkinlik ve örneklerin sayısının arttırılması gerektiği; İskender (2016) çalışmasında içeriklerin Türkçe Dersi Öğretim Programı ile uyuşmadığı sonuçlarına ulaşmışlardır. Bu çalışmada EBA içeriklerine yönelik yapılan olumsuz görüşler ile diğer araştırmaların sonuçları paralellik göstermektedir. Bu çalışmanın bulguları ile diğer araştırma sonuçlarından hareketle içeriklerin hem sayı hem de nitelik yönünden yetersiz olduğu kanaatine ulaşılabilir.

Konuşma becerilerine yönelik içeriklerin yetersiz olduğu görülmektedir. Bunun yanında içeriklerde eğlenceli, faydalı, ilgi çekici olması gibi olumlu görüşler de vardır. Konuşma becerisinin geliştirilmesi için iyi bir fırsat olan akıllı tahtalar görsel ve işitsel materyalleri bir araya getirme gibi bir olanağa sahiptir. Sadece öğretmenin rol model olduğu konuşma becerisi için EBA içerikleri sayesinde daha fazla örnek sunulabilir. Örnek içerikler konuşma becerisinin gelişmesinde daha etkili bir rol oynayacaktır. Düşünceleri daha iyi anlatmak için teknolojik materyallerden yararlanılması, öğrenme sürecini hızlandıracak ve öğrenmeyi daha etkili kılacaktır (Umağan, 2007: 152). Diğer alanlara göre biraz daha fazla beceri gerektiren konuşma alanı için mevcut içerikler ve eklenecek yeni içerikler bu öğrenme alanı için önemli bir fayda sağlayacaktır.

Dinleme bölümü ile ilgili içeriklere yönelik görüşlerde konuşmaya göre daha fazla olumsuz yorum bulunmaktadır. Bu eleştirilerde metinlerin çeşitlendirilmesi gerektiği vurgulanmaktadır. Çeşitlilik, millîlik, farklı seslerin eklenmesi metinler için önerilen niteliklerdir. "mp3" formatındaki dinleme metinlerinin akıllı tahtalarda daha etkin ve verimli olacağı bir gerçektir. Görsel ve işitsel öğelerin birleştirilmiş olması bulgularda olumlu bir nitelik olarak vurgulanmıştır. Medya ortamı sunan akıllı tahtalar yeni içeriklerle dinleme eğitimine olumlu katkılar sağlayacaktır. Dinleme becerisi bilgiye ulaşmayı, teknolojiden yararlanmayı daha kolay kılmaktadır (Güneş, 2014: 94). Dinleme ve teknoloji arasındaki bu ilişkiyi faydaya dönüştürmek yine etkili içeriklerle mümkün olacaktır.

Okumaya yönelik olumlu görüşler biraz fazla olsa da olumsuz görüşler yine ağır basmaktadır. Görüşlerde akıllı tahtada okuma çalışmalarının ilgi çekici olduğuna değinilmiş. Dijital ortamlarda sunulacak okuma materyallerinin öğrencinin okuma becerisine olumlu katkı sağladığı söylenebilir. Tabletlerden ve akıllı tahtadan sunulabilecek zengin içeriğin öğrencilerin okuma alışkanlığının gelişmesine de olumlu katkı sağlayacaktır. Okumaya yönelik yeni içeriklerin yanında kitaplar bölümüne öğrencilerin okuyabileceği güncel ve klasik kitaplar içerik olarak eklenebilir.

Yazma içeriklerine yönelik görüşlerde olumsuzluk diğerlerine göre daha fazladır. Yazma becerisinin bireysel bir uygulama alanı olmasından dolayı öğrencinin etkin katılabileceği bir durum söz konusu değildir. Tablet dağıtılırsa böyle bir imkân oluşabilir. Yine de etkili içeriklerle, örnek sunumlarla yazma becerisine etki edilebilir. Mevcut olan içeriklerin de yetersiz olduğunu öğretmenler ifade etmiştir. Yazma üzerinde daha fazla durulması gereken bir alan olarak karşımıza çıkmaktadır. 
Dil bilgisi içerik sayısı fazla olan alanlardan biridir. Dil bilgisi bilgi ağılıklı ve bu alana yönelik hazır bilgilerin bulunması içerik hazırlamada bu alana kayma göstermiş olabilir. Bu bölümde yine diğer alanlarda olduğu gibi eksiklikler bulunmaktadır. İçeriğin az ve yetersiz olduğu vurgulansa da olumlu anlamda içeriklerin mevcut olduğu vurgulanmıştır. Kodlardan hareketle en başarılı bölümün dil bilgisi alanı olduğunu söyleyebiliriz.

EBA (2017) hedeflediği; farklı, zengin ve eğitici içerikler sunmak, içerikle ilgili ihtiyaçlara cevap vermek, sosyal ağ yapısıyla kullanıcıların bilgi alışverişinde bulunabilmelerini sağlamak, zengin ve gittikçe büyüyen arşiviyle derslere katkı sağlamak, bilgiyi öğrenirken aynı zamanda yeniden yapılandırabilmek ve bilgiden bilgi üretmek, farklı öğrenme becerisine sahip öğrencileri de kapsamak, bütün öğretmenleri ortak bir paydada buluşturarak eğitime el birliğiyle yön vermelerini sağlamak ilkelerine kısmen ulaştığı görülmektedir. EBA içerik odaklı olan çok kapsamlı hedefler belirlemiştir. Ancak EBA ile ilgili yapılan çalışmalarda ve bu çalışmada bu hedeflere kısmen ulaştığı görülmektedir. İçerik temelli olan EBA platformunun amaçladığı içerik hedeflerine ulaşmak için yeni çalışmalar yapılabilir. Bu çalışmaların özellikle içerik oluşturmaya yönelik olması gerekir. Altın ve Kalelioğlu (2015); Baz (2016); Pamuk, Çakır, Ergün, Yılmaz ve Ayas (2013) öğretmenlere yönelik hizmet içi eğitim kursları ve formatör öğretmenler aracılığıyla bu eksikliklerin giderilebileceğini vurgulamaktadırlar. Eren ve Avcı (2016) e-içerik hazırlamak için gerek zaman gerekse teknoloji bilgilerinin olmamasının önemli bir engel oluşturduğunu vurgulamaktadır. EBA içeriği geliştirmede en önemli paydaş olan öğretmenlerin yeniden bilgilendirilmesi ve içerik hazırlama konusunda eğitilmesi gerekmektedir. Öğretmenin teknolojinin sınıfa entegresinde merkezi bir rol oynadığı (Chen, Looi ve Chen, 2009) unutulmamalıdır. Öğretmenlerin bu olanakların öğretim sürecine nasıl entegre edileceğini düşünmeleri kritik önem taşımaktadır (Hutchison ve Woodward, 2014). Dil öğretmenlerinin\% 82'si mesleki gelişim eksikliğinin teknoloji entegrasyonunun önünde bir engel olduğuna inanmaktadırlar (Hutchison ve Woodward, 2014). Bu eksiklik iyi düşünülmüş ve planlanmış kurslarla giderilebilir. EBA içeriklerini zenginleştirmek için öğretmenler MEB tarafından kursa tabi tutulmuş ancak bunun yeterli olmadığı görülmektedir. EBA sitesine içerik geliştirmek için programlar eklenmiştir. Ancak bu programları etkin kullanması için öğretmenlere rehberlik edilmesi gerektiği görülmektedir. EBA' ya içerik hazırlamak için basit ara yüzlü programlar dahi eklenmesine rağmen içerik yönünden amaca ulaşılamamıştır. Her şey düşünülerek oluşturulmuş EBA platformunun daha aktif kullanımı için yeni çalışmaların kaçınılmaz olduğu görülmektedir. EBA'nın önemini daha iyi kavratabilecek kurslar ve seminerler verilmelidir. Bilgi ve teknoloji insansız kullanılamaz, geliştirilemez (Güneş, 2014: 1). EBA içerikleri de ancak öğretmenlerin katılımıyla istenilen düzeye ulaşabilir. Öğretmenleri yeni öğretim teknolojileriyle buluşturmak ve derslerine uygun materyal geliştirebilmelerini sağlamak amacıyla 
gerek öğretmen yetiştiren kurumlarda gerekse sistem içinde hizmet içi eğitim çalışmaları ile yeterli eğitimi vermekte yarar vardır (Karadağ ve Maden, 2014: 288).

Günümüz öğretmeni, eğitim teknolojisinin tüm olanakları düşünerek, anadili öğretimini daha ilginç, daha etkili ve daha verimli bir duruma getirmek için çeşitli araç ve gereçten yararlanmayı bir ilke olarak benimsemelidir (Kavcar, Oğuzkan ve Hasırcı, 2016: 21). Türkçe öğrenme alanlarına yönelik içeriğin yetersiz oluşu kanaati sadece kurum temelli bir durum değildir. EBA' nın en önemli paydaşı olan öğretmenlerin teknolojiyi dersle bütünleştirme ve içeriği etkin kullanamama sorunun da bir gerçek olduğu göz önünde bulundurulmalıdır.

\section{Kaynaklar}

Abe, P. ve Jordan, N. A. (2013). Integrating Social Media into the Classroom Curriculum. About Campus, 18(1), 1-32.

Ağır, A. (2014). Etkileşimli Tahtalar İ̧̧in Orta Öğretim Coğrafya Videolarının Değerlendirilmesi: Öğretmen Görüşleri. Hasan Ali Yücel Eğitim Fakültesi Dergisi, 11(2), 31-37.

Aktaş, I., Özmen, H. \& Türkan, S. (2013). FATiH Projesi ile Sınıflara Kazandırılan Etkileşimli Tahtaların Kullanııma Düzeyleri. 7. Uluslararası Bilgisayar ve Öğretim Teknolojileri Sempozyumu, https://www.researchgate.net/profile/Idris_Aktas/publication/301350918_FATIH_Projesi_ile_Siniflara _Kazandirilan_Etkilesimli_Tahtalarin_Kullanilma_Duzeyleri/links/5714b98908aeff315ba3d033.pdf?orig in=publication_list adresinden 20 Ocak 2017 tarihinde alınmıştır.

Aktay, S. ve Keskin, T. (2016). Eğitim Bilişim Ağı (EBA) İncelemesi. Eğitim Kuram ve Uygulama Araştırma Dergisi, 2(3) 27-44.

Altın, H. M. ve Kalelioğlu, F. (2015). Fatih Projesi ile ilgili Öğrenci ve Öğretmen Görüşleri. Başkent University Journal of Education, , 2(1), 89-105.

Ateş, M., Çerçi A., \& Derman S. (2015). Eğitim Bilişim Ağında Yer Alan Türkçe Dersi Videoları Üzerine Bir Inceleme. Sakarya University Journal of Education, 5(3), 105-117.

Aydınözü, D., Sözcü, U. ve Akbaş, V. (2016). Coğrafya Öğretiminde EBA İçeriklerinin Öğrenci Başarısına Etkisi. Karadeniz Sosyal Bilimler Dergisi, 8(15).

Baz, F. Ç. (2016). Teknik, Donanım ve İçerik Yönüyle Fatih Projesinin Değerlendirilmesi. Gümüşhane Üniversitesi Sosyal Bilimler Enstitüsü, 7(15), 196-209.

Bekleyen, N. (2015). Dil Öğretimi. Ankara: Pegem Akademi.

Bello, A. A. (2014). Impact of Technology Interventions on Student Achievement in Rural Nigerian Schools. Walden Dissertationsand Doctoral Studies, Walden University Scholar Works.

Chang, K. E., Sung, Y. T., \& Hou, H. T. (2006). Web-based Tools for Designing and Developing Teaching Materials for Integration of Information Technology intolnstruction. Educational Technology \& Society, 9 (4), 139-149.

Chen, F. H., Looi, C. K., \& Chen, W. (2009). Integrating Technology in The Classroom: A Visual Conceptualization of Teachers' Knowledge, Goals and Beliefs. Journal of ComputerAssisted Learning, 25(5), 411-501.

Choy, D., Angela, F. L., \& Gao, W. P. (2009). Student Teachers' Intentions and Actions on Integrating Technology intoTheir Classrooms during Student Teaching: A Singapore Study. Journal of Research on Technology in Education, 42(2), 175-195.

Demircioğlu, G. ve Yadigaroğlu, M. (2014). Kimya Öğretmenlerinin Fatih Projesine Illişkin Görüşleri. Eğitim ve Öğretim Araştırmaları, 3(2), 302-310. 
Digregorio, P. ve Lojeski, S. K. (2010). "The Effects of Interactive White Boards (IWB) on Student Performance and Learning: A Literature Review. J. Educational Technology Systems, 38(3), 255-312.

Dursun, A., Kırbaş, i., \& Yüksel, M.E. (2015). Fırsatları Artırma ve Teknolojiyi İyileştirme Hareketi (FATiH) Projesi ve Proje Üzerine Bir Değerlendirme. Inet-Tr'15, XX. Türkiye'de Internet Konferansı, İstanbul Üniversitesi.

Dursun, Ö. Ö., Kuzu, A., Kurt, A. A., Güllüpınar, F., \& Gültekin, M. (2013). Okul Yöneticilerinin FATiH Projesinin Pilot Uygulama Sürecine iliş̧kin Görüşleri. Trakya Üniversitesi Eğitim Fakültesi Dergisi, 3(1), 100-113.

EBA (2017). Eğitimde Bilişim Ağı. http://fatihprojesi.meb.gov.tr/icerik/adresinden 04 Ocak 2017'de alınmıştır.

Eden, S. ve Eshet-Alkalai Y. (2013). The Effect Of Format On Performance: Editing Text in Print Versus Digital Formats. British Journal of Educational Technology. 44(5), 846-856.

Eren, E. Ve Avcl, Z. Y. (2016). E-Content Development Under School-University Collaboration: A Case Study Analysis Based on Technology Integration Planning Model. Uşak Üniversitesi Sosyal Bilimler Dergisi, 9(2), 210-234.

Güneş, F. (2014). Türkçe Öğretimi Yaklaşımlar ve Modeller. Ankara: PegemAkedemi.

Günşen, A. (2006). Ölçünlü Türkçede Yerelleşme Sorunu. Gürer G., Boz (Ed.), Türkçenin Çağdaş Sorunları, içinde (s.165-204). Ankara: Gazi Kitabevi.

Güzel, A. ve Karatay, H. (2014). Türkçe Öğretimi El Kitabı. Ankara: Pegem Akademi.

Hutchison A. ve Woodward, L. (2014). A Planning Cycle for Integrating Digital Technology. The Reading Teacher,67(6), 455-464.

İskender, H. (2016). Eğitim Bilişim Ağı'nda Bulunan 7. Sınıf Türkçe Dersi Videolarının Illköğretim Türkçe Dersi (6, 7, 8. Sınıflar) Öğretim Programıyla Uyumu. Adıyaman Üniversitesi Sosyal Bilimler Enstitüsü Dergisi, $8(24)$.

Karadağ, Ö. ve Maden, S. (2014). Yazma Egitimi: Kuram, Uygulama, Ölçme ve Değerlendirme. Güzel A., Karatay H.(Ed.), Türkçe Öğretimi El Kitabı, içinde (s.265- 301). Ankara: Pegem Akademi.

Karatay, H. (2014). Okuma Eğitimi: Kuram, Uygulama, Ölçme Ve Değerlendirme. Güzel A., Karatay H.(Ed.), Türkçe Öğretimi El Kitabı, içinde (s.221- 260). Ankara: Pegem Akademi.

Kavcar, C., Ferhan, O., \& Hasırcı, S. (2016). Türkçe Öğretimi: Türkçe ve Sınıf Öğretmenleri İçin. Ankara: Anı Yayıncilık.

Kearney, M. ve Schuck, S.(2008). Exploring Pedagogy With Interactive White Boards in Australian Schools. Australian Educational Computing, 23(1),8-14.

Korkmaz, F. ve Ünsal, S. (2016). Okul Öncesi Öğretmenlerin "Teknoloji” Kavramına İlişkin Metaforik Algılarının Incelemesi. Mustafa Kemal Üniversitesi Sosyal Bilimler Enstitüsü Dergisi Mustafa Kemal University Journal of Graduate School of Social Sciences, 13(35), 194-212.

MEB. (2016). Türkçe Öğretim Programı. http://ttkb.meb.gov.tr/program2.aspx/program2.aspx?islem=1\&kno=247 adresinden 04 Ocak 2017'de alınmıştır.

MEB (2017). Eğitimde FATiH Projesi. http://fatihprojesi.meb.gov.tr/proje-hakkinda/ adresinden 1 Ocak 2017'de alınmıştır.

Nuhoğlu, M. M., Hüseyin, T., \& Ertuğrul, K. (2007). Türkçe Öğretiminde Tiyatro ve Uygulamalar. Ankara: Maya Akademi Yayın Dağııım.

Öz, F. (2011). Uygulamalı Türkşe Öğretimi. Ankara: Anı Yayıncılık. 
Pamuk, S., Çakır, R., Ergün, M., Yılmaz, B., \& Ayas, C. (2013). Öğretmen ve Öğrenci Bakış Açısıyla Tablet PC ve Etkileşimli Tahta Kullanımı: FATiH Projesi Değerlendirmesi. Kuram ve Uygulamada Eğitim Bilimleri, 13(3), 1799-1822.

Parlakyıldız, H. (2014). İlk Okuma ve Yazma Öğretimi. Güzel A., Karatay H.(Ed.), Türkçe Öğretimi El Kitabı, içinde (s. 571-605). Ankara: Pegem Akademi.

Sever, S. (2003). Türkçe Öğretiminde Yeni Yapılanma Çalışmaları. Türklük Bilimi Araştırmaları Türkçe Öğretimi Özel Sayısı, 13(1).

Sevimli, E. ve Kul, Ü. (2015). Evaluation of the Contents of Mathematics Textbooks in Terms of Compliance to Technology: Case of Secondary School. Necatibey Eğitim Fakültesi Elektronik Fen ve Matematik Eğitimi Dergisi (EFMED), 9(1), 308-331.

Solmaz, O. (2015). İnternet ve Dil Öğretimi, Bekleyen N.(Ed.) Dil Öğretimi, içinde (s. 414-430). Ankara: Pegem Akademi.

Şahin, A. ve Şahin, E. (2007). Türkçe Öğretiminde Materyal Geliştirme. Kırkkılıç A., Akyol H. (Ed.) ilköğretimde Türkçe Öğretimi, içinde (309-349). Ankara: Pegem A Yayıncılık.

TÜiK (2016). Girişimlerde Bilişim Teknolojileri Kullanımı Araştırması, Hanelerde Bilişim Teknolojileri Kullanımı Araştırması. http://www.tuik.gov.tr/PreHaberBultenleri.do?id=2177916 adresinden Ocak 2017'de alınmıştır.

Tüysüz, C. ve Çümen, V. (2016). Eba Ders Web Sitesine Illişkin Ortaokul Öğrencilerinin Görüşleri. Uşak Üniversitesi Sosyal Bilimler Dergisi, 9(3).

Umağan, S. (2007). Dinleme Eğitimi. Kırkkılıç A., Akyol H.(Ed.) Ilköğretimde Türkçe Öğretimi, içinde (149-163). Ankara: Pegem A Yayıncılık.

Yağmur, K. (2011). Türkçe Ders Kitaplarının Üst Düzey Bilişsel Becerileri Geliştirme Yeterliliği. Ülper H.(Ed.) Türkçe Ders Kitabı Çözümlemeleri, içinde (s. 191-220). Ankara: Pegem Akademi.

Yalçın, A. (2012). Türkçe Öğretim Yöntemleri Yeni Yaklaşımlar. Ankara: Akçağ Basım Yayım Pazarlama.

Yaprak, Z. (2015).içerik Temelli Öğretim/Içcrik ve Dil Bütünleştirmeli Öğrenme. Bekleyen N.(Ed.) Dil Öğretimi, içinde (s.212-227). Ankara: Pegem Akademi.

Yelbay, Y. (2015). Sözcük Bilgisi Öğretimi. Bekleyen N.(Ed.) Dil Öğretimi, içinde (s.352-367). Ankara: Pegem Akademi.

Yıldırım, A. ve Şimşek, H. (2011). Sosyal Bilimlerde Nitel Araştırma Yöntemleri. Ankara: Seçkin Yayıncılık.

Yıldız, C., Okur, A., Arı, A., \& Yılmaz, Y.(2013). Yeni Öğretim Programına Göre Kuramdan Uygulamaya Türkçe Öğretimi. Ankara: Pegem Akademi. 